This document is the unedited Author's version of a Submitted Work that was subsequently accepted for publication in Journal of Medicinal Chemistry, copyright (C) American Chemical Society after peer review. To access the final edited and published work see http://pubs.acs.org/doi/abs/10.1021/acs.jmedchem.6b00685. 
This document is confidential and is proprietary to the American Chemical Society and its authors. Do not copy or disclose without written permission. If you have received this item in error, notify the sender and delete all copies.

\section{Non-Acidic Free Fatty Acid Receptor 4 Agonists with Antidiabetic Activity}

\begin{tabular}{|r|l|}
\hline Journal: & Journal of Medicinal Chemistry \\
\hline Manuscript ID & jm-2016-00685w.R1 \\
\hline Manuscript Type: & Article \\
\hline Date Submitted by the Author: & n/a \\
\hline Complete List of Authors: & $\begin{array}{l}\text { Azevedo, Carlos; Syddansk Universitet Det Naturvidenskabelige Fakultet, } \\
\text { Watterson, Kenneth; University of Glasgow } \\
\text { Wargent, Ed; University of Buckingham } \\
\text { Hansen, Steffen; Syddansk Universitet Det Naturvidenskabelige Fakultet, } \\
\text { Dept. of Physics, Chemistry and Pharmacy } \\
\text { Hudson, Brian; University of Glasgow, } \\
\text { Kępczyńska, Małgorzata; University of Buckingham } \\
\text { Dunlop, Julia; University of Glasgow } \\
\text { Shimpukade, Bharat; University of Southern Denmark } \\
\text { Christiansen, Elisabeth; Syddansk Universitet Det Naturvidenskabelige } \\
\text { Fakultet } \\
\text { Milligan, Graeme; University of Glasgow, } \\
\text { Stocker, Claire; University of Buckingham, Clore Laboratory } \\
\text { Ulven, Trond; University of Southern Denmark, IFK }\end{array}$ \\
\hline
\end{tabular}




\section{Non-Acidic Free Fatty Acid Receptor 4 Agonists}

\section{with Antidiabetic Activity}

Carlos M. G. Azevedo ${ }^{\dagger}$, Kenneth R. Watterson ${ }^{\dagger}$, Ed T. Wargent ${ }^{\S}$, Steffen V. F. Hansen ${ }^{\dagger}$, Brian D. Hudson ${ }^{+}$, Małgorzata A. Kępczyńska ${ }^{\S}$, Julia Dunlop ${ }^{+}$, Bharat Shimpukade ${ }^{\dagger}$, Elisabeth Christiansen $^{\dagger}$, Graeme Milligan ${ }^{\dagger}$, Claire J. Stocker ${ }^{\S}$, and Trond Ulven ${ }^{\dagger} *$

†Department of Physics, Chemistry and Pharmacy, University of Southern Denmark, Campusvej 55, DK-5230 Odense M, Denmark. ${ }^{*}$ Institute of Molecular, Cell and Systems Biology, College of Medical, Veterinary and Life Sciences, University of Glasgow, Glasgow G12 8QQ, Scotland, U.K. ${ }^{\S}$ Buckingham Institute for Translational Medicine, University of Buckingham, Hunter Street, Buckingham MK18 1EG, U.K. 
ABSTRACT. The free fatty acid receptor 4 (FFA4 or GPR120) has appeared as an interesting potential target for the treatment of metabolic disorders. At present, most FFA4 ligands are carboxylic acids that are assumed to mimic the endogenous long-chain fatty acid agonists. Here, we report preliminary structure-activity relationship studies of a previously disclosed non-acidic sulfonamide FFA4 agonist. Mutagenesis studies indicate that the compounds are orthosteric agonists despite the absence of a carboxylate function. The preferred compounds showed full agonist activity on FFA4 and complete selectivity over FFA1, although a significant fraction of these non-carboxylic acids also showed partial antagonistic activity on FFA1. Studies in normal and diet-induced obese (DIO) mice with the preferred compound 34 showed improved glucose tolerance after oral dosing in an oral glucose tolerance test. Chronic dosing of $\mathbf{3 4}$ in DIO mice resulted in significantly increased insulin sensitivity and a moderate but significant reduction in bodyweight, effects that were also present in mice lacking FFA1 but absent in mice lacking FFA4. 


\section{INTRODUCTION}

The free fatty acid receptor 4 (FFA4, also known as GPR120) has in recent years appeared as a new potential target for the treatment of metabolic diseases. ${ }^{1-7}$ The receptor was proposed as a possible antidiabetic and antiobesity target for the first time in 2005 when it was reported to be expressed in the intestinal tract and activated by dietary free fatty acids to stimulate incretin secretion, ${ }^{8}$ although this property of the receptor remains controversial. ${ }^{9}$ FFA4 was subsequently found also to be expressed in macrophages, liver and adipose tissue, and to mediate antiinflammatory and insulin sensitizing effects. ${ }^{10}$ The report that mice lacking FFA4 develop obesity, insulin intolerance and fatty liver when fed a high-fat diet and that a human population with a dysfunctional FFA4 variant has an increased risk of obesity supported a significant role of the receptor in metabolic diseases. ${ }^{11}$ Further support for this was recently provided by the finding that the selective FFA4 agonist Cpd A (Chart 1) increased insulin sensitivity and reduced inflammation and hepatic steatosis in mice fed a high-fat diet. ${ }^{12}$ Moreover, FFA4 is implicated in regulation of glucagon, ghrelin and somatostatin release, representing likely contributing mechanisms of the observed metabolic phenotype. ${ }^{13-16}$
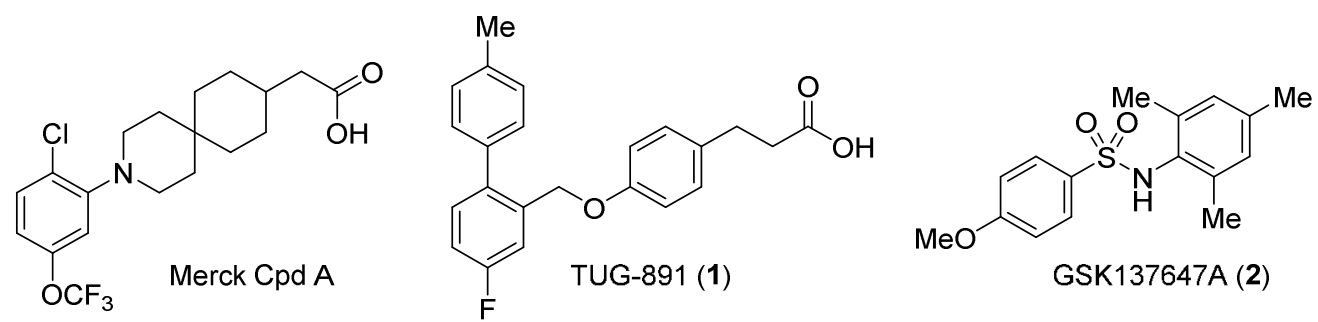

Chart 1. Representative FFA4 agonists

Although unsaturated and, in particular, omega-3 fatty acids were highlighted in the initial publications, ${ }^{8,10}$ it has become clear that FFA4 is activated by long-chain fatty acids with a profile that overlaps extensively with those that activate the more established antidiabetic target 
free fatty acid receptor 1 (FFA1/GPR40). ${ }^{17}$ In 2012, we disclosed TUG-891 (1, Chart 1) as the first potent and selective FFA4 agonist, optimized from a series of FFA1 agonists originally derived from fatty acids. ${ }^{18,19}$ However, the significantly higher potency of $\mathbf{1}$ at the murine (m) FFA1 resulted in a selectivity of 70-fold in a $\beta$-arrestin-2-based assay and of only 3 -fold in a calcium assay for mFFA4 over mFFA1, essentially rendering the compound a dual agonist in mice, at least with respect to signals and functions mediated by the induced elevation of $\mathrm{Ca}^{2+} .20$

In 2008, a patent from Banyu disclosed a series of non-acidic benzosultams as FFA4 agonists structurally distinct from other known FFA4 agonists. ${ }^{21}$ The structures were also markedly different from known FFA1 ligands and appeared to represent an opportunity to access FFA4 agonists with complete selectivity over FFA1. More recently, Sparks and co-workers reported a series of sulfonamide FFA4 agonists with GSK1237647A (2, Chart 1) as the preferred compound with $\mathrm{pEC}_{50}=6.3$ and a lack of activity on FFA1. However, this compound was also described as unsuitable for in vivo studies due to poor solubility. ${ }^{22}$ Herein, we report structure-activity relationship studies around these compound series, leading to the identification of a full FFA4 agonist with complete selectivity over FFA1. We further demonstrate activity in vivo and report beneficial results on glucose regulation, insulin sensitivity and bodyweight of the selected compound in DIO mice.

\section{SYNTHESIS}

The initial compounds were synthesized by nucleophilic aromatic substitution at 1,3-difluoro5-nitrobenzene, reduction of $\mathbf{3 a - c}$ to anilines $\mathbf{4 a - c}$, formation of the sulfonamides $\mathbf{5 a - c}$, reduction (6a-c) and cyclization to provide sultams 7-9, essentially following the synthetic strategy described in Banyu's patent (Scheme 1). ${ }^{21}$ Aniline 4a was also substrate for the synthesis of 
phthalimide 12 and for the acyclic sulfonamides 13 and 14. Acyclic sulfonamides, including 1519, were synthesized similarly from the corresponding sulfonyl chlorides and anilines.

Scheme 1. Synthesis of compounds using a previously described route ${ }^{a, 21}$

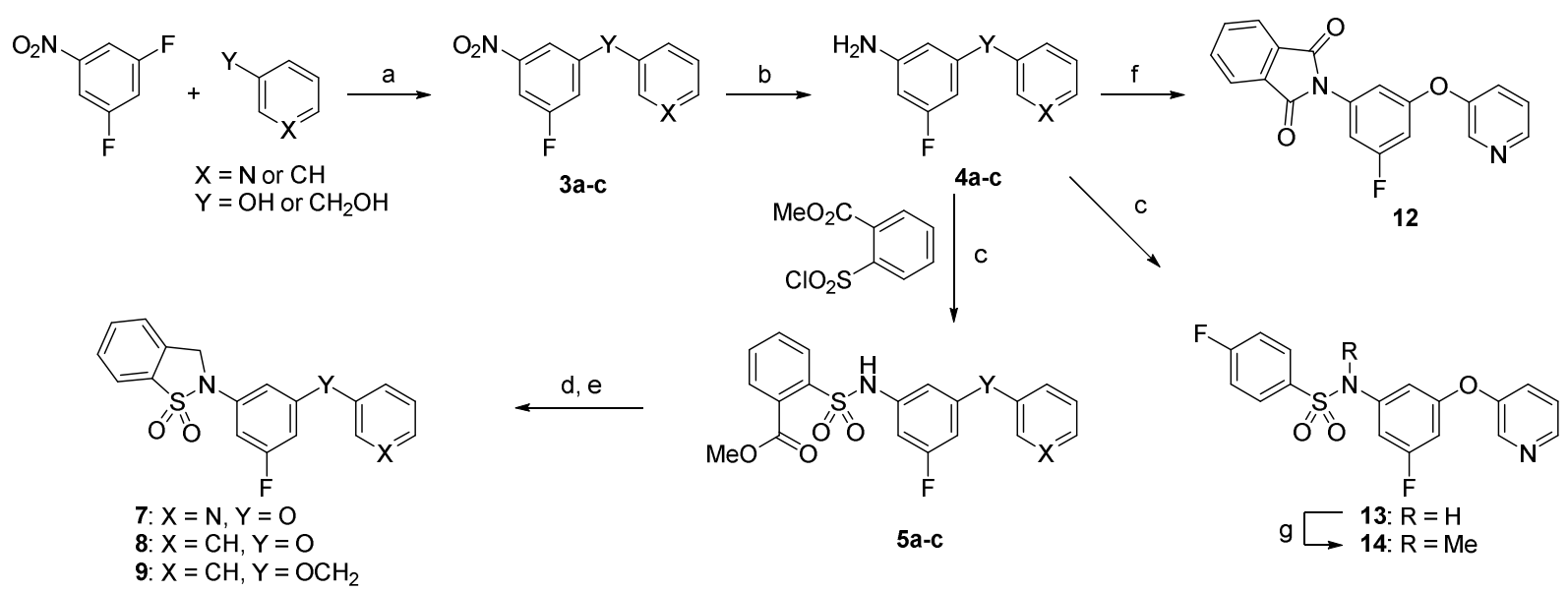

${ }^{a}$ Reagents and conditions: (a) $\mathrm{K}_{2} \mathrm{CO}_{3}, \mathrm{DMF}, 100{ }^{\circ} \mathrm{C}, 16 \mathrm{~h}$ (30-68\%). (b) $\mathrm{Y}=\mathrm{O}: \mathrm{NH}_{4} \mathrm{HCO}_{2}$, $\mathrm{Pd} / \mathrm{C}$, EtOH, $90{ }^{\circ} \mathrm{C}(\mu v), 10 \mathrm{~min}$ (quant.); $\mathrm{Y}=\mathrm{CH}_{2} \mathrm{O}: \mathrm{SnCl}_{2}, \mathrm{MeCN} / \mathrm{EtOH}(1: 1)$, refl., $1 \mathrm{~h}(86 \%)$. (c) Pyridine, rt, $16 \mathrm{~h}$ (50-96\%). (d) $\mathrm{LiAlH}_{4}$, THF, $0{ }^{\circ} \mathrm{C}, 0.5-2 \mathrm{~h}(48-95 \%)$; e) $\mathrm{PBr}_{3}, \mathrm{THF}, 0{ }^{\circ} \mathrm{C}$ to rt, $0.5 \mathrm{~h} ; \mathrm{Na}_{2} \mathrm{CO}_{3}$ (sat. aq.), $1 \mathrm{~h}$ (44-83\%). (f) phtalic anhydride, acetic acid, $100{ }^{\circ} \mathrm{C}, 16 \mathrm{~h} \mathrm{(68 \% );}$ (g) MeI, NaH, DMF, $0{ }^{\circ} \mathrm{C}$ to rt, $1 \mathrm{~h}(65-78 \%)$.

Since this synthetic route to the sultam is cumbersome and unsuitable for variations in the eastern part of the structure, a more straightforward coupling procedure was developed. Thus, the benzosultam intermediate 20, obtained from saccharin, was subject to copper(I)-catalyzed crosscoupling with 4-iodophenol followed by Ullmann coupling to give 22, with 1-bromo-3phenoxybenzene to give $\mathbf{2 3}$, and with 3-bromo-5-fluorophenol to give the central intermediate $\mathbf{2 5}$ (Scheme 2). Further Ullmann condensation of 25 with aryl bromides or iodides provided the target compounds (26-34). The monocyclic 24 was synthesized from 3-phenoxyaniline and 3chloropropanesulfonyl chloride (Scheme 3). Analogues with the central fluoro substituent removed (36) or replaced by chloro (38) were synthesized by nucleophilic aromatic substitution of 2-fluoropyridine with the respective halophenols followed by copper(I)-catalyzed crosscoupling with 20 (Scheme 4). 
Scheme 2. Synthesis of $N$-arylbenzosultams from saccharin ${ }^{a}$

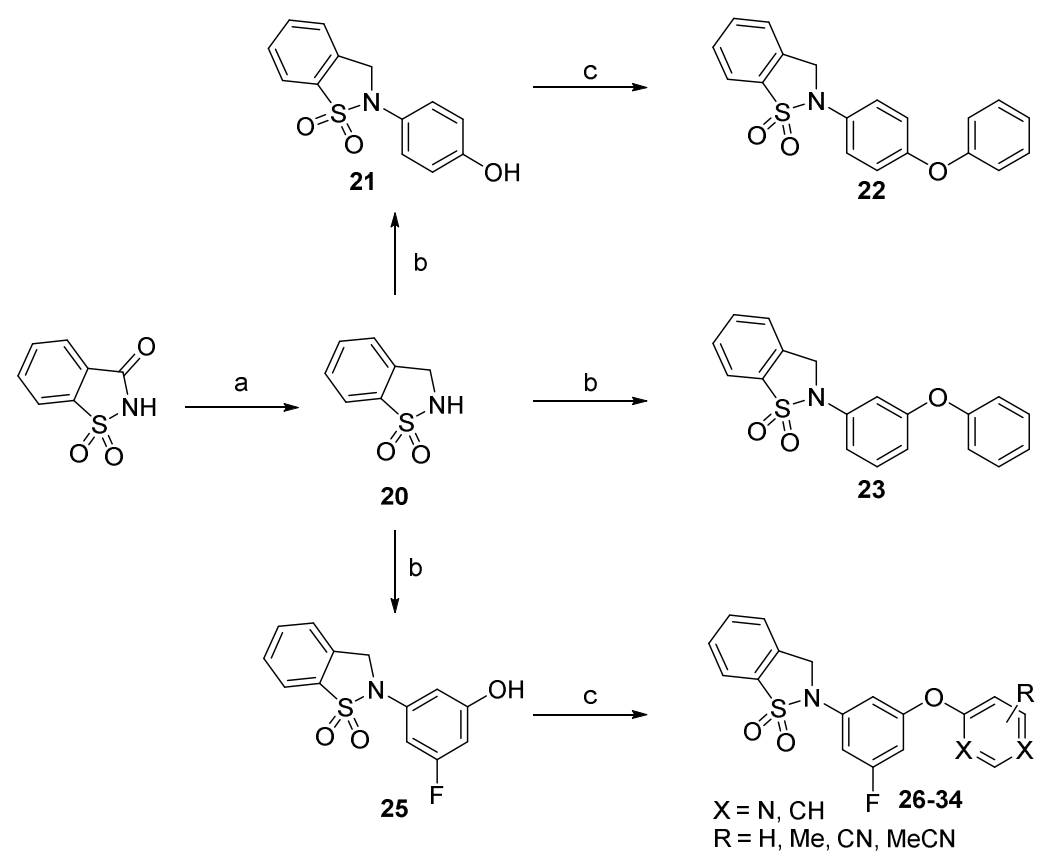

${ }^{a}$ Reagents and conditions: (a) $\mathrm{LiAlH}_{4}$, THF, $0{ }^{\circ} \mathrm{C}$ to $\mathrm{rt}, 16 \mathrm{~h}$ (78\%). (b) Aryl halide (4iodophenol, 1-bromo-3-phenoxybenzene or 3-bromo-5-fluorophenol), CuI, DMEDA, $\mathrm{K}_{2} \mathrm{CO}_{3}$, $\mathrm{MeCN}, 70{ }^{\circ} \mathrm{C}, 16 \mathrm{~h}(65-96 \%)$. (c) Aryl halide (Br or I), picolinic acid, CuI, $\mathrm{K}_{3} \mathrm{PO}_{4}$, DMSO, $90{ }^{\circ} \mathrm{C}$ (12-83\%), $24 \mathrm{~h}$.

Scheme 3. Synthesis of sultam $\mathbf{2 4}^{a}$

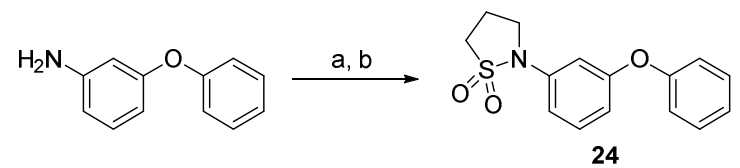

${ }^{a}$ Reagents and conditions: (a) 3-Chloropropanesulfonyl chloride, pyridine, $\mathrm{CH}_{2} \mathrm{Cl}_{2}$, rt, 16 h. (b) $\mathrm{K}_{2} \mathrm{CO}_{3}, \mathrm{DMF}, 50{ }^{\circ} \mathrm{C}, 16 \mathrm{~h}(72 \%$ over two steps).

Scheme 4. Synthesis of non-fluorinated analogues ${ }^{a}$

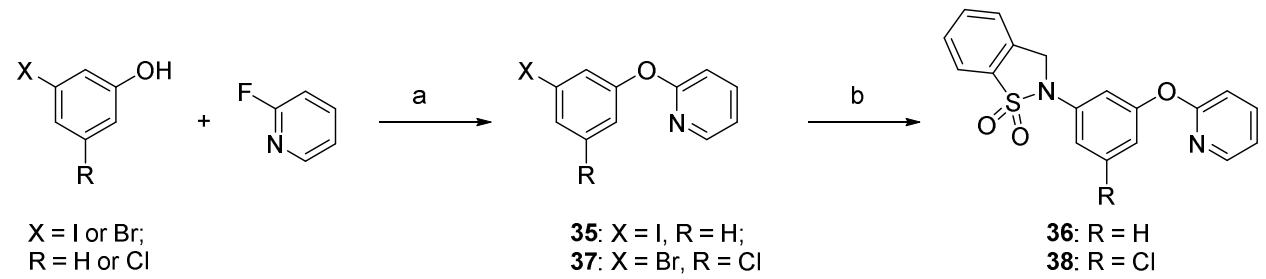

${ }^{a}$ Reagents and conditions: (a) $\mathrm{K}_{2} \mathrm{CO}_{3}$, DMF, $140{ }^{\circ} \mathrm{C}(\mu v), 4-5 \frac{1}{2} \mathrm{~h}(62-65 \%)$. b) 20, CuI, DMEDA, $\mathrm{K}_{2} \mathrm{CO}_{3}, \mathrm{MeCN}, 70{ }^{\circ} \mathrm{C}, 16 \mathrm{~h}(61-88 \%)$. 


\section{RESULTS AND DISCUSSION}

The compounds were screened on human (h) FFA4 in a $\beta$-arrestin- 2 recruitment assay and compounds of particular interest were further tested in a $\mathrm{Ca}^{2+}$ mobilization assay and on hFFA1. ${ }^{18}$ The sultam 7, disclosed as an FFA4 agonist with $\mathrm{pEC}_{50}$ of 6.74 in the Banyu patent, ${ }^{21}$ showed somewhat lower activity in our assays with a $\mathrm{pEC}_{50}$ of 6.36 in the $\beta$-arrestin-2 assay and 6.52 in the $\mathrm{Ca}^{2+}$ assay (Table 1). Notably, the compound did not show any activity on FFA1 at concentrations up to $100 \mu \mathrm{M}$. The FFA1 agonist $\mathbf{1 0}^{23}$ was found to also act as a full FFA4 agonist (see the Supporting Information), ${ }^{18}$ and has been used herein as a reference compound.

Table 1. Initial exploration of the pyridine ring of 7

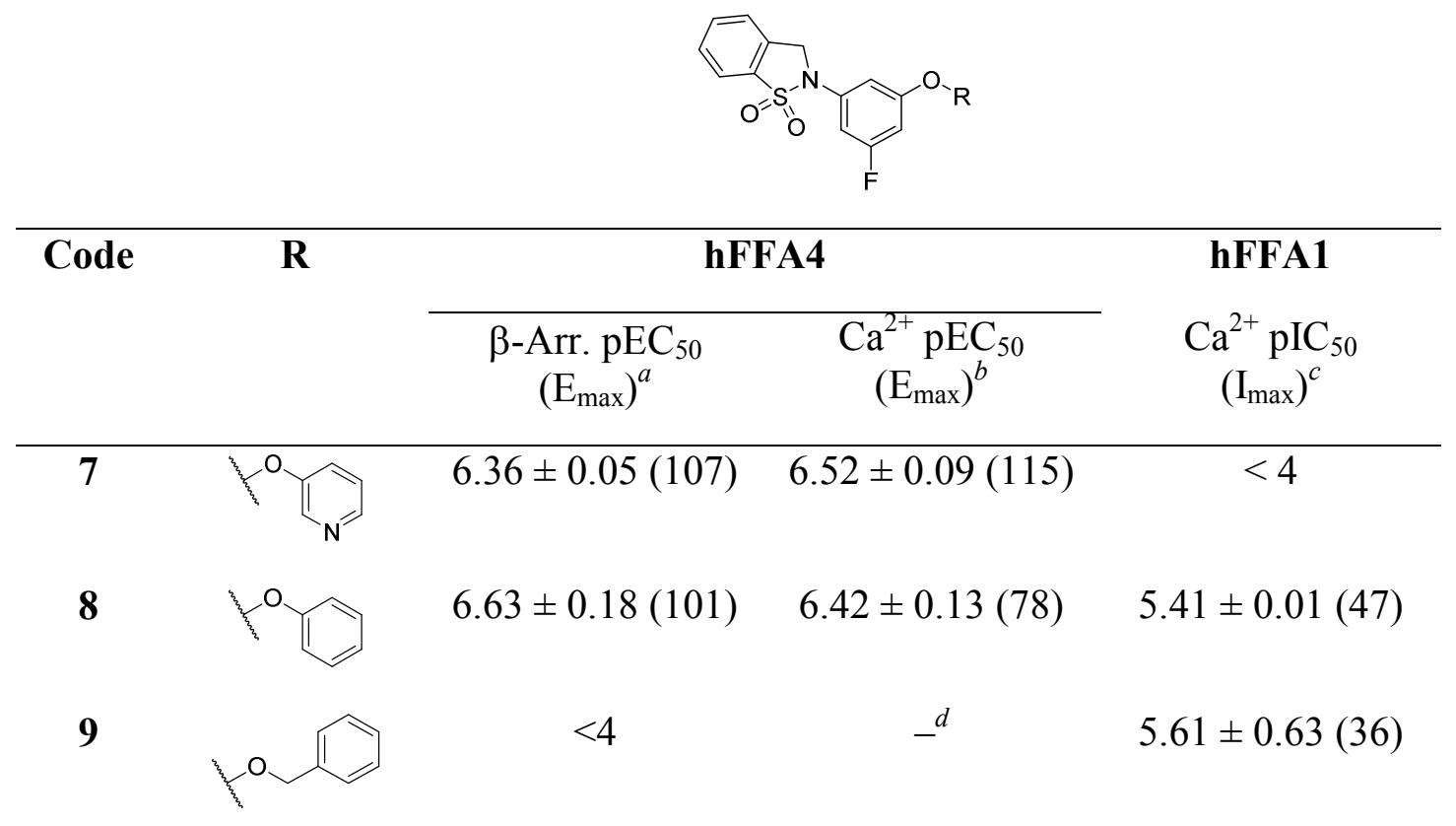

\footnotetext{
${ }^{a}$ BRET-based $\beta$-arrestin-2 recruitment based FFA4 assay. Efficacy $\left(\mathrm{E}_{\max }\right)$ is relative to $100 \mu \mathrm{M}$ 10 (3-(4-(o-tolylethynyl)phenyl)propanoic acid, TUG-424). ${ }^{23} \mathrm{Ca}^{2+} \mathrm{FFA} 4$ assay. Efficacy (E $\left.\max \right)$ is relative to $100 \mu \mathrm{M} \mathrm{10}{ }^{c}$ Tested in the FFA1 $\mathrm{Ca}^{2+}$ assay as agonists and antagonists. $\mathrm{I}_{\max }$ denotes \% reduction of the response of $300 \mathrm{nM} \mathrm{10}$. All compounds were inactive as FFA1 agonists. ${ }^{d}$ Not tested.
} 
Studies with 7 on FFA4 mutants directed at the orthosteric binding site revealed that the activity depends critically on Arg99 $9^{2.64}$, the residue identified as the key anchoring point for the carboxylate group of free fatty acids and orthosteric ligands such as $\mathbf{1}^{24}$ This observation was initially surprising in light of the distinctly different structure and the lack of any acidic group. Compound 7 was also affected by other mutations that impact the activity of $\mathbf{1}$ and $\alpha$-linolenic acid, strongly suggesting that 7 also binds to the orthosteric site (Table S1). ${ }^{24}$ Thus, mutations that eliminate or significantly reduce the activity of $\alpha$-linolenic acid and $\mathbf{1}\left(\mathrm{W} 104 \mathrm{~A}, \mathrm{~F} 115^{3.29} \mathrm{~A}\right.$, $\mathrm{W} 207^{5.38} \mathrm{~A}, \mathrm{~F} 211^{5.42} \mathrm{~A}, \mathrm{~W} 277^{6.48} \mathrm{~A}$ and $\mathrm{F} 304^{7.36} \mathrm{~A}$ eliminate activity of both, $\mathrm{F} 88^{2.53} \mathrm{~A}, \mathrm{I} 284^{5.66} \mathrm{~A}$, F303 ${ }^{7.35} \mathrm{H}$ and $\mathrm{T} 310^{7.42} \mathrm{~A}$ significantly reduce activity of both $\alpha$-linolenic acid and $\mathbf{1}, \mathrm{T} 119^{3.33} \mathrm{~A}$, $\mathrm{I} 126^{3.40} \mathrm{~A}, \mathrm{~N} 215^{5.46} \mathrm{~A}, \mathrm{I} 280^{6.51} \mathrm{~A}, \mathrm{I} 281^{6.52} \mathrm{~F}$ only reduce the activity of $\mathbf{1}$, see Table $\mathrm{S} 1$ ) also affect the activity of 7 in a similar manner. Exceptions were $\mathrm{W} 1000^{2.65} \mathrm{~A}$ and $\mathrm{L} 114^{3.28} \mathrm{~A}$, which affected 1 but not 7, as well as $\mathrm{V} 212^{5.43} \mathrm{~A}$, and $\mathrm{F} 311^{7.43} \mathrm{~A}$, which each significantly decreased potency of 7, while only producing smaller non-significant decreases in the potency of 1. Computational modeling indicated favored alternative docking poses in the orthosteric site of FFA4 with 7 directly interacting with Arg99 $9^{2.64}$ by hydrogen bonds either to the sultam oxygen atoms or to the pyridyl nitrogen. To investigate the most likely orientation, the phenyl analogue 8 , lacking the pyridyl interaction possibility, was synthesized and found more potent on FFA4 than 7, indicating the sulfonamide as the Arg99 2.64 interaction point (Figure 1). 


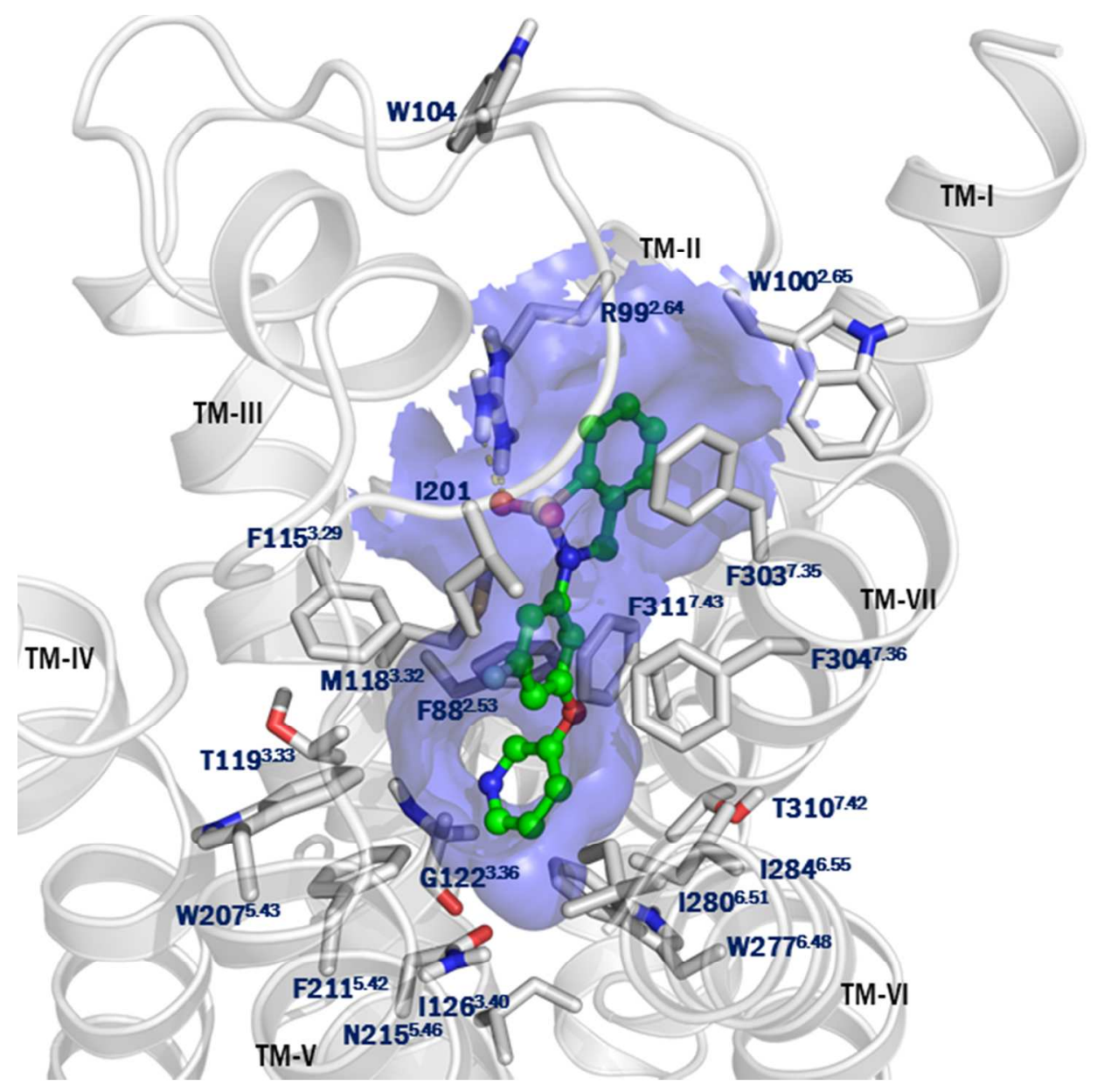

Figure 1. Docking pose for 7 in a homology model of hFFA4. Residues where mutation significantly affects the functional activity of 7 have been displayed.

To probe the importance of the sulfonamide moiety, phthalimide 12, also exemplified in the Banyu patent but without activity data, ${ }^{21}$ was produced and found to have 10 -fold lower activity than 7 and low partial efficacy, indicating that the sulfonamide is important for agonist activity but that replacement by other hydrogen bond acceptors is possible. The acyclic sulfonamide $\mathbf{1 3}$, containing a weakly acidic group (calculated $\left.\mathrm{pK}_{\mathrm{a}} \quad 7.7\right)^{25}$ exhibited further reduced activity. Interestingly, $N$-methylation to give the non-acidic ring-opened analogue $\mathbf{1 4}$ resulted in complete loss of activity, possibly reflecting that planarity between the aromatic ring and the S-N bond is a requirement. 
Table 2. Lead structures and western part variations

\begin{tabular}{|c|c|c|c|c|}
\hline \multirow[t]{2}{*}{ Code } & \multirow[t]{2}{*}{ Structure } & \multicolumn{2}{|c|}{ hFFA4 } & \multirow{2}{*}{$\begin{array}{c}\text { hFFA1 } \\
\mathrm{Ca}^{2+} \mathrm{pIC}_{50} \\
\left(\mathrm{I}_{\max }\right)^{c}\end{array}$} \\
\hline & & $\begin{array}{l}\mathrm{BRET} \mathrm{pEC}_{50} \\
\left(\mathrm{E}_{\max }\right)^{a}\end{array}$ & $\begin{array}{c}\mathrm{Ca}^{2+} \mathrm{pEC}_{50} \\
\left(\mathrm{E}_{\max }\right)^{b}\end{array}$ & \\
\hline 12 & & $5.30 \pm 0.08(45)$ & ${ }^{d}$ & $-{ }^{d}$ \\
\hline 13 & & $4.78 \pm 0.15(39)$ & $-{ }^{d}$ & $n r^{e}$ \\
\hline 14 & & $\mathrm{nr}^{e}$ & ${ }^{d}$ & $\mathrm{nr}^{e}$ \\
\hline 15 & & $5.27 \pm 0.36(76)$ & $\mathrm{nr}^{h}$ & $5.09 \pm 0.15(68)$ \\
\hline 16 & & $5.45 \pm 0.01(52)$ & $\mathrm{nr}^{h}$ & $4.89 \pm 0.10(95)$ \\
\hline 17 & & $\mathrm{nr}^{e}$ & $-{ }^{d}$ & $4.97 \pm 0.15(57)$ \\
\hline 2 & (Chart 1) & $6.31 \pm 0.09(82)$ & $-^{d}$ & $\mathrm{nr}^{e}$ \\
\hline 18 & & $\mathrm{nr}^{e}$ & $-{ }^{d}$ & $\mathrm{nr}^{e}$ \\
\hline 19 & & $\mathrm{nr}^{e}$ & $\mathrm{nr}^{e}$ & $5.00 \pm 0.09(100)$ \\
\hline 22 & & $\mathrm{nr}^{e}$ & $-{ }^{d}$ & $\mathrm{nr}^{e}$ \\
\hline 23 & & $6.61 \pm 0.07(95)$ & $6.68 \pm 0.06(105)$ & $6.76 \pm 1.34(39)$ \\
\hline 24 & & $\mathrm{nr}^{e}$ & $\mathrm{nr}^{e}$ & $\mathrm{nr}^{e, f}$ \\
\hline
\end{tabular}


${ }^{a}$ BRET-based $\beta$-arrestin-2 recruitment based FFA4 assay. Efficacy $\left(\mathrm{E}_{\max }\right)$ is relative to $\mathbf{1 0 .}$ ${ }^{b} \mathrm{Ca}^{2+}$ FFA4 assay. Efficacy $\left(\mathrm{E}_{\max }\right)$ is relative to $10 .{ }^{c}$ Tested in the FFA1 Ca ${ }^{2+}$ assay as agonists and antagonists. All compounds were inactive as FFA1 agonists. $\mathrm{I}_{\max }$ denotes \% reduction of the response of $300 \mathrm{nM} \mathrm{10} .{ }^{d}$ Not tested. ${ }^{e}$ No response up to $100 \mu \mathrm{M} .{ }^{f}$ Tested as antagonist in the FFA1 $\mathrm{Ca}^{2+}$ mobilization assay with $20 \mathrm{nM}$ of 11 (3-(4-((2-(cyanomethyl)phenyl)ethynyl)phenyl)propanoic acid, TUG-770). ${ }^{26}$

Related to 13, the sulfonamide DC260126 (15) has been described as an FFA1 antagonist and was, somewhat surprisingly, reported to improve insulin sensitivity and $\beta$-cell function in rats and $\mathrm{db} / \mathrm{db}$ mice. ${ }^{27,28}$ We confirmed its FFA1 antagonist activity $\left(\mathrm{pIC}_{50}=5.09\right)$ but found that the compound also acts as an FFA4 agonist in the $\beta$-arrestin- 2 recruitment assay although it was devoid of activity in the $\mathrm{Ca}^{2+}$ assay (Table 2), and thus represents a relatively low-potency, but completely $\beta$-arrestin-biased, FFA4 agonist. Since FFA4 is proposed to mediate antiinflammatory effects via the $\beta$-arrestin pathway, it cannot be excluded that the tendency to insulin sensitization observed with this compound is mediated by FFA4.

Replacing the butyl of $\mathbf{1 5}$ by phenoxy (16) gave a compound with similar FFA1 antagonistic and FFA4 agonistic properties. $N$-Methylation of the potentially acidic sulfonamide (17) led to loss of FFA4 activity but preserved FFA1 antagonism. The related sulfonamide $\mathbf{2}$ (Chart 1) was recently reported as a selective FFA4 agonist. ${ }^{22}$ We confirmed a pEC $_{50}$ of 6.31 in the $\beta$-arrestin-2 assay. Replacement of the para-fluoro of $\mathbf{1 6}$ with methoxy (18) akin to $\mathbf{2}$ resulted in complete loss of activity, as did para-phenoxyphenyl sultam 22, whereas the moderate FFA1-antagonistic activity was maintained with a para-methyl substituent (19). Interestingly, removing the metafluoro of the phenyl analogue $\mathbf{8}$ resulted in a compound (23) with preserved potency in both the $\beta$-arrestin- 2 and calcium assay on FFA4 as well as preserved partial antagonist activity on FFA1, whereas removing the benzene ring fused to the sultam (24) resulted in a compound devoid of activity on both FFA4 and FFA1, indicating a critical role of this ring. 
Explorations of the western part of the structure suggested that the benzosultam system was favored. Turning attention back to the eastern site, the eastern phenyl ring of $\mathbf{8}$ was scanned with the non-polar methyl substituent $(\mathbf{2 6}, \mathbf{2 7}, \mathbf{2 8})$ and the polar cyano (29-31) and meta-cyanomethyl (32) substituents, in all cases these resulted in decreased potency with para-substituents being somewhat better tolerated (Table 3).

Table 3. Exploration of the central and eastern parts

27




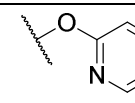

F $\quad 6.91 \pm 0.04(98) \quad 6.63 \pm 0.13(130)$

$<4$

36

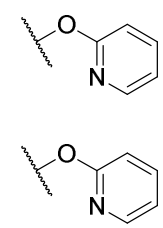

$\mathrm{H} \quad 5.81 \pm 0.11(102)$

$5.99 \pm 0.19(93)$

$<4$

38

$\mathrm{Cl} \quad 6.86 \pm 0.10(113)$

$7.41 \pm 0.18(78)$

$<4^{f}$

${ }^{a}$ BRET-based $\beta$-arrestin-2 recruitment based FFA4 assay. Efficacy $\left(\mathrm{E}_{\max }\right)$ is relative to $100 \mu \mathrm{M}$ 10. ${ }^{b} \mathrm{Ca}^{2+}$ FFA4 assay. Efficacy $\left(\mathrm{E}_{\max }\right)$ is relative to $100 \mu \mathrm{M} \mathrm{10} .{ }^{c}$ Tested in the FFA1 Ca ${ }^{2+}$ assay as agonists and antagonists. All compounds were inactive as FFA1 agonists. $\mathrm{I}_{\max }$ denotes \% reduction of the response of $300 \mathrm{nM} \mathrm{10} .{ }^{d}$ No response up to $100 \mu \mathrm{M} .{ }^{e}$ Not tested. ${ }^{f}$ Tested as antagonist in the FFA1 $\mathrm{Ca}^{2+}$ mobilization assay with $20 \mathrm{nM} \mathrm{11.}{ }^{26}$

Further investigation of $\mathbf{8}$ revealed antagonistic activity on FFA1, but without the ability to completely block the agonist response (i.e. "partial antagonism", Table 1). A similar effect was seen with all substituted analogues exhibiting noticeable agonistic activity $\left(\mathrm{EC}_{50}<10 \mu \mathrm{M}\right)$ on FFA4. These results are surprising because they indicate that this compound series also has the ability to interact with and modulate FFA1 despite its structural dissimilarity from other FFA1 agonists and the absence of an acidic functional group. However, the inability of the compounds to completely block activity of $\mathbf{1 0}$ suggests non-competitive binding and allosteric interaction with FFA1.

In contrast to the phenoxy compounds, the pyridines $7,33,13,14$ did not show any sign of agonistic or antagonistic activity on FFA1. These structures were therefore explored further by altering the attachment point at the pyridine. Thus, the 4-pyridyl (33) derivative resulted in a 3fold reduced potency, whereas the 2-pyridyl (34) gratifyingly showed a 3.5-fold increased potency to achieve an $\mathrm{EC}_{50}$ of $128 \mathrm{nM}$.

Finally, the importance of the meta-fluoro substituent at the central ring of $\mathbf{3 4}$ was assessed. Removal of the fluoro substituent in $\mathbf{3 6}$ resulted in a 10-fold reduced potency and indicated, 
contrary to $\mathbf{8}$ vs $\mathbf{2 3}$, that the meta-fluoro contributes to the potency of $\mathbf{3 4}$. In contrast, substitution of fluoro by chloro in $\mathbf{3 8}$ led to preserved activity in the $\beta$-arrestin- 2 recruitment assay and an $\mathrm{EC}_{50}$ of $40 \mathrm{nM}$ in the $\mathrm{Ca}^{2+}$ assay, a 6 -fold increase in potency relative to 34 , albeit with reduced efficacy.

Overall, $\mathbf{3 4}$ and $\mathbf{3 8}$ stood out as the most potent FFA4 agonists in both the $\beta$-arrestin- 2 and the $\mathrm{Ca}^{2+}$ assays with essentially equal activity in the former. Although $\mathbf{3 8}$ appeared more potent in the $\mathrm{Ca}^{2+}$ assay, the compound showed only partial agonist activity, whereas $\mathbf{3 4}$ was a full agonist in both assays as well as less lipophilic ( $\Delta \mathrm{C} \log \mathrm{P} \sim 0.5)$. Compound 34 showed no activity at the other free fatty acid receptors FFA1, FFA2 or FFA3 at up to $30 \mu \mathrm{M}$, indicating $>300$-fold selectivity. Experimental $\log D_{7.4}$ measurements showed identical lipophilicity for 34 and 7 (3.17 and 3.12, respectively). Solubility studies for compounds 7, 34 and $\mathbf{3 8}$ in PBS indicated progressively lower solubility with $\mathbf{3 8}$ being virtually insoluble $(11,1.3$ and $0.1 \mu \mathrm{M}$, respectively), however, the solubility of the two latter in fasting state simulated intestinal fluid (FaSSIF) gave a somewhat better picture for $\mathbf{3 4}(14 \mu \mathrm{M}$ for $\mathbf{3 4}$ and $0.9 \mu \mathrm{M}$ for $\mathbf{3 8})$. Thus, $\mathbf{3 4}$ was selected for in vivo studies. The low solubility of the compound did not cause any problems in relation to these. Prior to the mouse studies, the activity and specificity of $\mathbf{3 4}$ and the two other most potent and selective agonists, $\mathbf{7}$ and $\mathbf{3 8}$, on the mFFA4 and mFFA1 were investigated. Completely preserved activity was confirmed for all three compounds in the Gq-dependent $\mathrm{Ca}^{2+}$ mobilization assay on mFFA4 $\left(\mathrm{pEC}_{50}=7.08 \pm 0.05,6.83 \pm 0.08\right.$ and $7.14 \pm 0.08$ for $\mathbf{7}, \mathbf{3 4}$ and 38, respectively), with no activity detected up to $100 \mu \mathrm{M}$ on mFFA1. Further, $\mathbf{3 4}$ was also tested in the $\beta$-arrestin assay, confirming full agonistic activity with $\mathrm{pEC}_{50}=6.32 \pm 0.06$, again with no sign of activity on mFFA1. Compound $\mathbf{3 4}$ also failed to induce a response when tested on the 
FFA4 R99 ${ }^{2.64} \mathrm{Q}$ mutant, supporting the notion that this compound binds as indicated for 7 in Figure 1.

FFA4 has been reported to mediate free fatty acid promoted incretin release and to improve glucose tolerance, ${ }^{8,12}$ and mice lacking FFA4 show impaired glucose homeostasis, an effect believed to involve improper regulation of glucagon secretion. ${ }^{14}$ Thus, the effect of $\mathbf{3 4}$ as well as 7 in a glucose tolerance test was investigated by oral dosing prior to an oral glucose challenge. This resulted in significant lowering of plasma glucose levels for both compounds compared to vehicle (Figure 2).

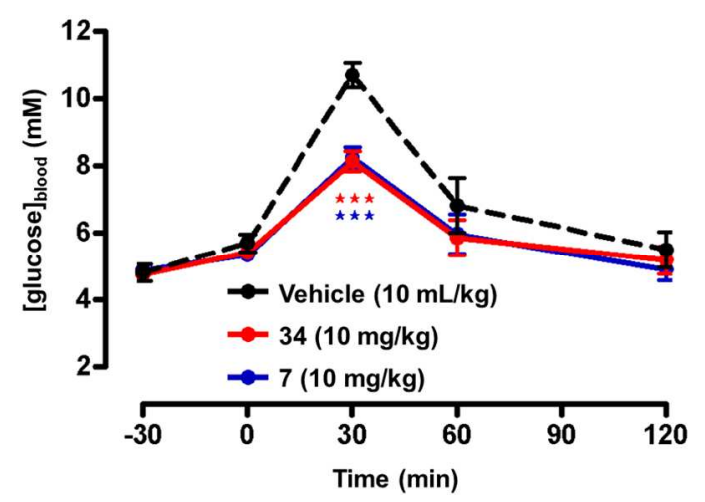

Figure 2. FFA4 agonists 34 and 7 lower plasma glucose concentrations compared to vehicle after oral dosing at $10 \mathrm{mg} / \mathrm{kg} 15 \mathrm{~min}$ before oral glucose challenge ( $\mathrm{n}=6$ mice per group, $* \mathrm{p} \leq 0.05 ; * * \mathrm{p} \leq 0.01, * * * \mathrm{p} \leq 0.001$, two-way ANOVA with Bonferoni post hoc test).

FFA4 has attracted high interest as a potential antidiabetic target in particular because of results indicating that the receptor mediates insulin sensitization, anti-inflammatory effects, protection of pancreatic islets, and that it may even counteract obesity. ${ }^{3-6,10,11,29}$ However, each of these is difficult to assess satisfactorily in acute treatment studies. To evaluate the effects of 34 on some of these, a chronic treatment study in DIO mice was performed with daily dosing of 10 $\mathrm{mg} / \mathrm{kg} 34$ over a three week period. Mice lacking FFA4 were included to assess and confirm receptor specific activity of the ligand. The wild-type mice were littermates of the FFA4(-/-) 
animals. As observed in normal mice, a glucose challenge 15 min after dosing in DIO mice on the first day significantly reduced plasma glucose levels in 34-treated wild-type mice compared to vehicle-treated wild-type mice, whereas $\mathbf{3 4}$ had no effect on glucose levels in the FFA4(-/-) animals (Figure 3, top). The effect was significant in the wild-type animals also when calculated relative to $t=-30 \mathrm{~min}$ (see the Supporting Information). A significantly increased insulin level was observed 30 min after challenge for the wild-type mice treated with $\mathbf{3 4}$ relative to vehicle treated wild-type mice, whereas the difference was absent in mice lacking FFA4 (Figure 3, bottom). This confirms that the effect of $\mathbf{3 4}$ on glucose excursion when dosed 15 minutes before the challenge is mediated by FFA4. Studies to investigate the mechanism of this effect are in progress.

wild-type

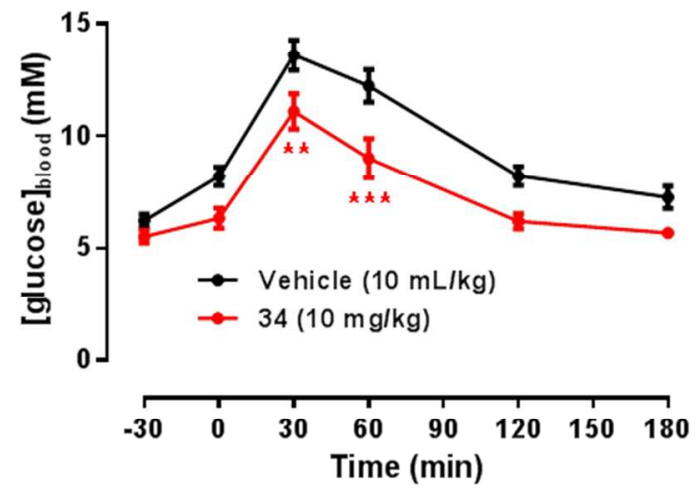

wild-type

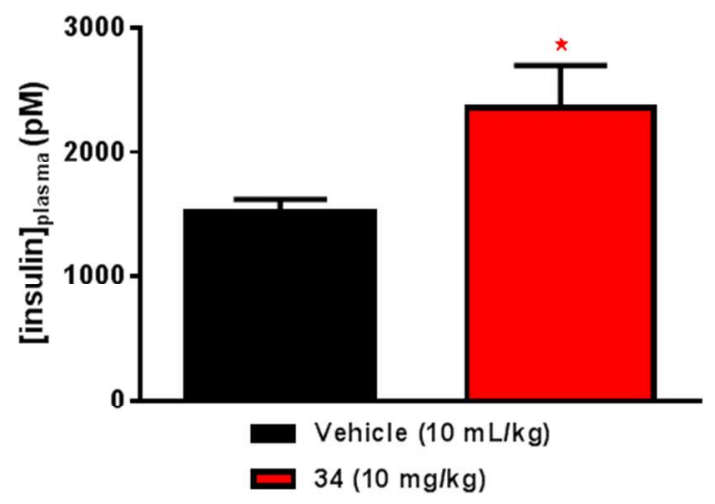

$\operatorname{FFA4}(-1-)$

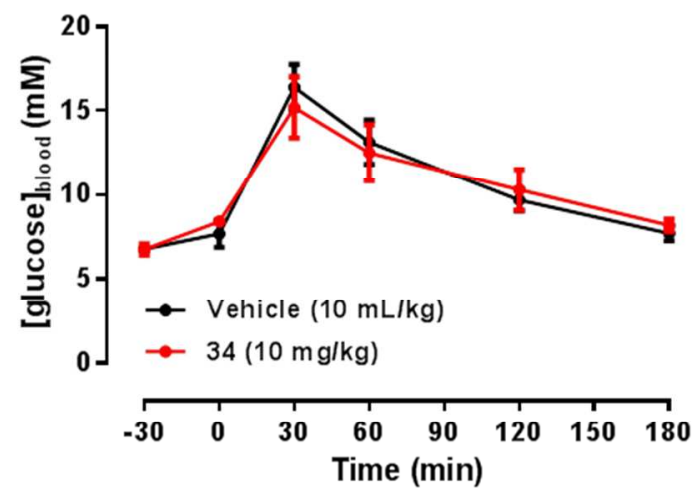

$\operatorname{FFA4}(-/-)$

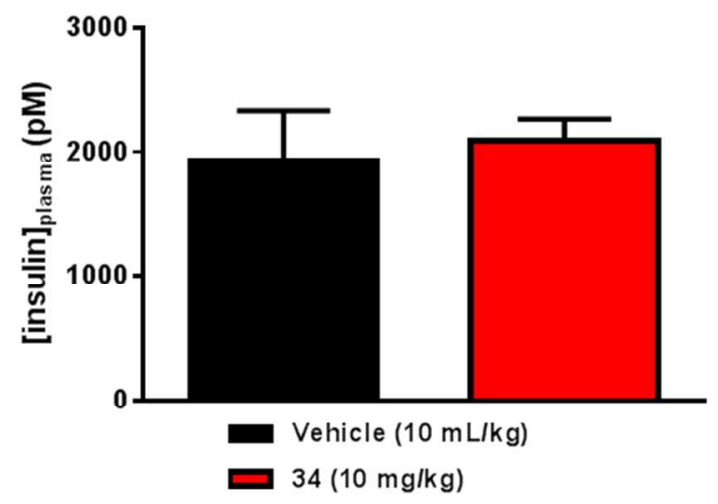


Figure 3. Plasma glucose levels (top) and insulin levels at $\mathrm{t}=30 \mathrm{~min}$ (bottom) after an acute oral glucose tolerance test 15 min after dosing with $\mathbf{3 4}$ or vehicle in DIO wild-type and DIO FFA4(-/) mice on day 0 ( $\mathrm{n}=9$ mice per group; $* \mathrm{p}=<0.05, * * \mathrm{p}=<0.01, * * * \mathrm{p}<0.001$, two-way ANOVA with Bonferroni post hoc test).

After treatment over 21 days, the fasting insulin levels of the $\mathbf{3 4}$ treated wild-type DIO mice was significantly reduced compared to vehicle treated mice, whereas no difference was observed between the FFA4(-/-) groups (Figure 4, top). These results indicate that $\mathbf{3 4}$ promotes insulin sensitization in mice through activation of FFA4. An oral glucose tolerance test on day 21 (Figure 4, bottom) showed an even more robust effect than on day 0 , presumably an effect of increased insulin sensitization.
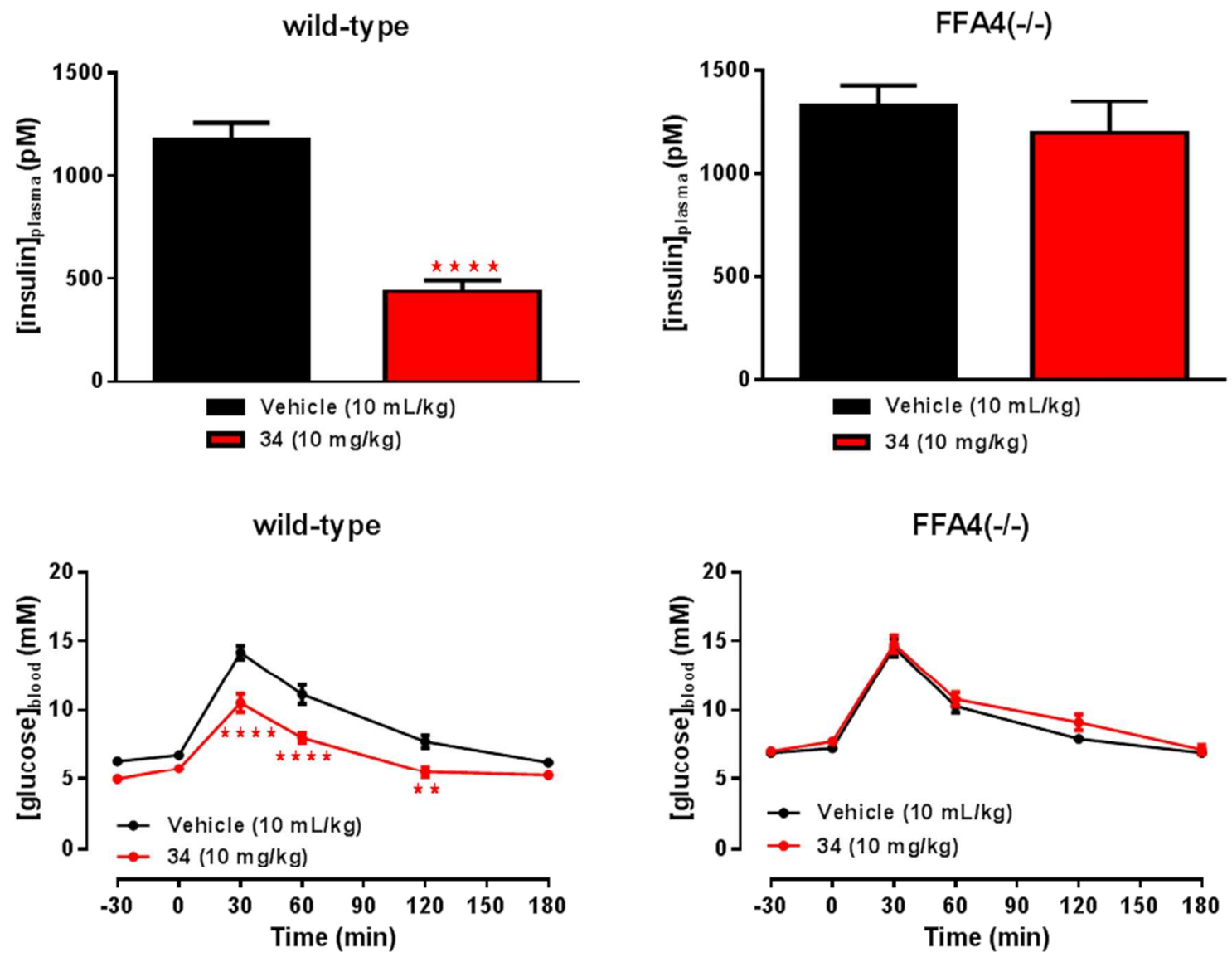
Figure 4. Fasting insulin levels after chronic dosing with $\mathbf{3 4}$ for 21 days (top) and oral glucose tolerance test at day 21 (bottom) $(\mathrm{n}=9, * \mathrm{p} \leq 0.05, * * \mathrm{p} \leq 0.01, * * * \mathrm{p} \leq 0.001, * * * * \mathrm{p} \leq 0.0001$, oneway ANOVA with Dunnett's post hoc test).

Previous studies have linked FFA4 to obesity by demonstrating a correlation between expression and obesity and have indicated an increased risk of obesity with p.R270H FFA4 variant in European populations or with deletion of the receptor in mouse, ${ }^{5,11}$ although a recent study failed to find a similar association in a Danish population. ${ }^{30}$ No significant effect was observed on either food or water intake over the course of dosing with $\mathbf{3 4}$ for 21 days in either the wild-type or FFA4(-/-) animals. Treatment with 34 did, however, result in a reduction in bodyweight in the wild-type mice of 3-4 grams (7-9\%) towards the end of the study, whereas no effect, or even a weak trend towards weight gain, was observed in the FFA4(-/-) animals (Figure 5). These results support the notion that FFA4 may represent a potential anti-obesity target, an effect that would be an important add-on to regulation of glucose homeostasis in an antidiabetic drug.

wild-type

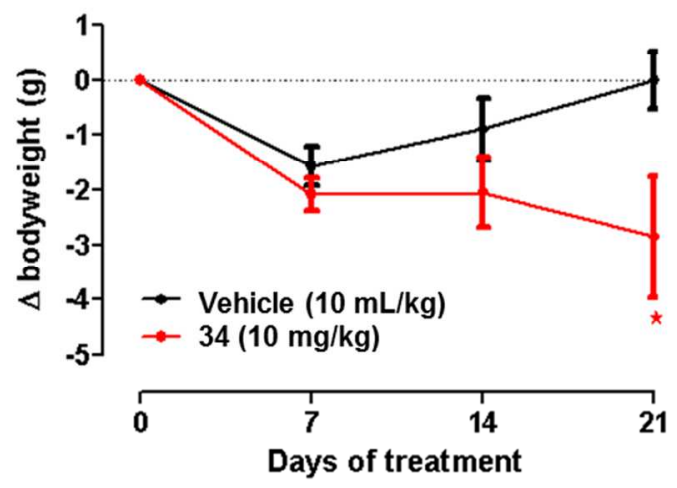

FFA4(-/-)

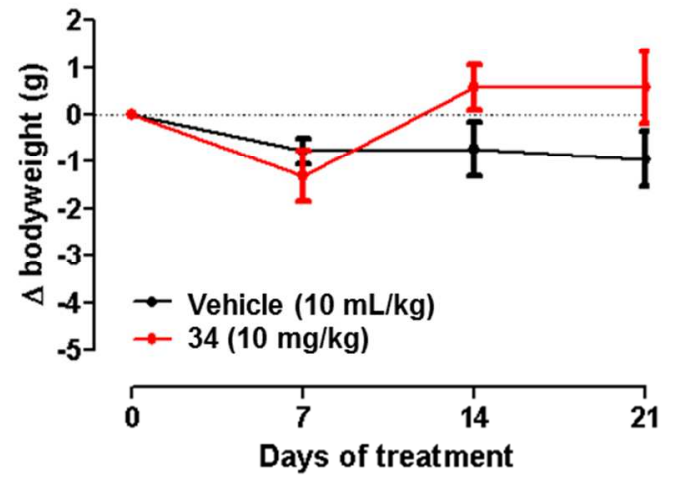

Figure 5. Bodyweight change in DIO wild-type and FFA4(-/-) mice over 21 days of once daily dosing (10 mg/kg, po) with 34 ( $\mathrm{n}=9$ mice per group, * $\mathrm{p} \leq 0.05$; two-way ANOVA with Bonferroni post hoc test). 
CONCLUSION

Most currently known FFA4 agonists are carboxylic acids assumed to mimic the endogenous free fatty acid agonists. Most of these also exhibit some degree of activity on FFA1. In the search for highly selective FFA4 agonists, we investigated a non-acidic benzosultam ligand known from the patent literature and conducted a preliminary structure-activity relationship study around this scaffold. Interestingly, mutagenesis studies indicated that these compounds also bind to the same site as $\alpha$-linolenic acid and $\mathbf{1}$ and also require carboxylate interaction partner Arg99 ${ }^{2.64}$ for activity despite the absence of a carboxylate. Given the limited overall homology between FFA1 and FFA4, even though they are both activated by overlapping sets of medium- and long-chain free fatty acids, it was surprising that a sub-series of these compounds also interacted with FFA1 to produce partial blockade of this receptor. Compound 34, a full FFA4 agonist with comparable potency in both $\mathrm{Ca}^{2+}$ - and $\beta$-arrestin-2-based assays, showed complete selectivity over FFA1 and other free fatty acid receptors. Its distinctly different structure from the carboxylic acid FFA4 agonists currently used as tool compounds makes $\mathbf{3 4}$ a suitable orthogonal tool in combination with these for further studies of the function of FFA4. The compound was investigated in vivo and was found to lower plasma glucose levels after an oral glucose challenge when dosed orally 15 minutes prior to the challenge, an effect that was confirmed to be mediated by FFA4 as this was not observed in animals lacking FFA4. Furthermore, 34 robustly increased insulin sensitivity after chronic dosing in DIO mice and led to moderately reduced bodyweight over the course of the study, despite no significant effects on food or water intake. Altogether, $\mathbf{3 4}$ is a non-acidic 
full agonist of FFA4 with complete selectivity over FFA1 that shows antidiabetic and antiobesity effects after chronic oral dosing in DIO mice, corroborating FFA4 as a promising new antidiabetic target.

\section{EXPERIMENTAL SECTION}

\section{Synthesis}

Commercial starting materials and solvents were used without further purification. THF was freshly distilled from sodium/benzophenone. Water was filtered and demineralized (Milli-Q). TLC was performed on TLC Silica gel 60 F254 plates and visualized at $254 \mathrm{~nm}$ and/or by staining with phosphomolybdic acid, vanillin, or $\mathrm{KMnO}_{4}$ stains. Petroleum ether (PE) refers to alkanes with bp 60-80 ${ }^{\circ} \mathrm{C}$. Microwave reactions were performed in a Biotage Initiator $^{+}$ microwave reactor. Purification by flash chromatography was carried out using silica gel 60 (0.040-0.063 mm, Merck). ${ }^{1} \mathrm{H}$ and ${ }^{13} \mathrm{C}$ NMR spectra were recorded at 400 and $101 \mathrm{MHz}$, respectively, on Bruker Avance III 400 at $300 \mathrm{~K}$. High-resolution mass spectra (HRMS) were obtained on a Bruker micrOTOF-Q II (ESI). Purity was determined by HPLC and confirmed by inspection of NMR spectra. HPLC analysis was performed using a Dionex $120 \mathrm{C} 18$ or a Gemini C18 column $(5 \mu \mathrm{m}, 4.6 \times 150 \mathrm{~mm})$; flow: $1 \mathrm{~mL} / \mathrm{min} ; 10 \% \mathrm{MeCN}$ in water $(0-1 \mathrm{~min}), 10-100 \%$ $\mathrm{MeCN}$ in water (1-10 min), 100\% MeCN (11-15 min), with both solvents containing 0.05\% TFA or $0.1 \% \mathrm{HCOOH}$ as modifier; UV detection at $254 \mathrm{~nm}$. All test compounds were of $\geq 95 \%$ purity unless otherwise stated.

2-(4-Hydroxyphenyl)-2,3-dihydrobenzo[d] $]$ isothiazole-1,1-dioxide (21). To 20 (250 mg, 1.48 mmol), $\mathrm{CuI}$ (42 mg, $0.22 \mathrm{mmol})$, 4-iodophenol (390 mg, $1.77 \mathrm{mmol})$ and anhydrous $\mathrm{K}_{2} \mathrm{CO}_{3}(615$ $\mathrm{mg}, 4.45 \mathrm{mmol})$ under argon were added dry and freshly degassed acetonitrile $(5 \mathrm{~mL})$ and 
DMEDA $(80 \mu \mathrm{L}, 0.75 \mathrm{mmol})$. The reaction mixture was heated at $70{ }^{\circ} \mathrm{C}$ for $16 \mathrm{~h}$. The reaction was then quenched with aqueous $\mathrm{HCl}(2 \mathrm{~N}, 10 \mathrm{~mL})$ and the aqueous phase was extracted with EtOAc $(3 \mathrm{x})$. The combined organic phases were dried $\left(\mathrm{Na}_{2} \mathrm{SO}_{4}\right)$ and concentrated. The crude product was purified by flash chromatography (EtOAc/PE, 1:1) and the product obtained recrystallized from EtOAc/PE (1:1) to give 21 as a yellow solid (232 mg, 65\%). ${ }^{1} \mathrm{H}$ NMR (400 MHz, acetone- $\left.d_{6}\right): 8.51(\mathrm{~s}, 1 \mathrm{H}), 7.89(\mathrm{~d}, J=7.6 \mathrm{~Hz}, 1 \mathrm{H}), 7.78(\mathrm{t}, J=7.6 \mathrm{~Hz}, 2 \mathrm{H}), 7.69(\mathrm{t}, J=7.6$ $\mathrm{Hz}, 2 \mathrm{H}), 7.41(\mathrm{~d}, J=8.8 \mathrm{~Hz}, 2 \mathrm{H}), 6.95(\mathrm{~d}, J=8.8 \mathrm{~Hz}, 2 \mathrm{H}), 4.93(\mathrm{~s}, 2 \mathrm{H}) .{ }^{13} \mathrm{C} \mathrm{NMR}(100 \mathrm{MHz}$, acetone- $\left.d_{6}\right): 156.8,136.4,134.5,133.7,130.2,129.5,125.94,125.93,121.8,116.9,51.9$. HRMS (ESI) calcd for $\mathrm{C}_{13} \mathrm{H}_{11} \mathrm{NNaO}_{3} \mathrm{~S}[\mathrm{M}+\mathrm{Na}]^{+}$284.0352, found 284.0347. HPLC $t_{\mathrm{R}}=9.4 \mathrm{~min}, 99.6 \%$.

2-(4-Phenoxyphenyl)-2,3-dihydrobenzo[d] isothiazole-1,1-dioxide (22). To 21 (75 mg, 0.29 mmol), iodobenzene (48 $\mu \mathrm{L}, 0.43 \mathrm{mmol})$, copper iodide (11 mg, $0.06 \mathrm{mmol})$, picolinic acid (14.8 $\mathrm{mg}, 0.12 \mathrm{mmol})$ and $\mathrm{K}_{3} \mathrm{PO}_{4}(123 \mathrm{mg}, 0.58 \mathrm{mmol})$ under argon was added dry DMSO $(0.5 \mathrm{~mL})$ and the reaction mixture was heated at $90{ }^{\circ} \mathrm{C}$ for $24 \mathrm{~h}$. The temperature was then allowed to reach rt and the reaction mixture was partitioned between water and EtOAc. The aqueous phase extracted with EtOAc $(2 x)$ and the combined organic phases were washed with brine, dried $\left(\mathrm{Na}_{2} \mathrm{SO}_{4}\right)$ and concentrated. The crude product was purified by flash chromatography (EtOAc/PE, 3:7) and recrystallized from EtOAc/PE (2:1) to give 22 as light yellow solid (80 mg, 83\%). ${ }^{1} \mathrm{H}$ NMR (400 MHz, $\left.\mathrm{CDCl}_{3}\right): 7.88(\mathrm{~d}, J=7.6 \mathrm{~Hz}, 1 \mathrm{H}), 7.66(\mathrm{td}, J=7.6,0.9 \mathrm{~Hz}, 1 \mathrm{H}), 7.59$ $(\mathrm{t}, J=7.6 \mathrm{~Hz}, 1 \mathrm{H}), 7.49-7.44(\mathrm{~m}, 3 \mathrm{H}), 7.35(\mathrm{t}, J=8.0 \mathrm{~Hz}, 2 \mathrm{H}), 7.12(\mathrm{t}, J=7.4 \mathrm{~Hz}, 1 \mathrm{H}), 7.12$ $(\mathrm{d}, J=8.9 \mathrm{~Hz}, 2 \mathrm{H}), 7.12(\mathrm{~d}, J=7.7 \mathrm{~Hz}, 2 \mathrm{H}), 4.84(\mathrm{~s}, 2 \mathrm{H}) .{ }^{13} \mathrm{C} \mathrm{NMR}\left(100 \mathrm{MHz}, \mathrm{CDCl}_{3}\right): 157.1$, $155.2,135.0,133.0,132.5,131.6,129.9,129.5,124.4,123.5,123.5,121.6,120.0,118.9,50.8$. HRMS (ESI) calcd for $\mathrm{C}_{19} \mathrm{H}_{15} \mathrm{NNaO}_{3} \mathrm{~S}[\mathrm{M}+\mathrm{Na}]^{+} 360.0665$, found 360.0653. HPLC $t_{\mathrm{R}}=12.3$ $\min , 99.7 \%$. 
2-(3-Phenoxyphenyl)-2,3-dihydrobenzo $[d]$ isothiazole-1,1-dioxide (23). The title compound was obtained as described for 21 using 20 (100 mg, $0.59 \mathrm{mmol})$ and 3-bromodiphenylether (129 $\mu \mathrm{L}, 0.71 \mathrm{mmol})$ as starting materials. The crude product was purified by flash chromatography (EtOAc/PE, 3:7) and the product recrystallized from EtOAc/PE (2:1) to give 23 as a white solid (175 mg, 88\%). ${ }^{1} \mathrm{H}$ NMR (400 MHz, $\left.\mathrm{CDCl}_{3}\right): 7.86$ (d, $\left.J=7.6 \mathrm{~Hz}, 1 \mathrm{H}\right), 7.66(\mathrm{t}, J=7.6 \mathrm{~Hz}, 1 \mathrm{H})$, $7.58(\mathrm{t}, J=7.6 \mathrm{~Hz}, 1 \mathrm{H}), 7.47(\mathrm{~d}, J=7.6 \mathrm{~Hz}, 1 \mathrm{H}), 7.39-7.31(\mathrm{~m}, 3 \mathrm{H}), 7.27(\mathrm{dd}, J=8.2,1.3 \mathrm{~Hz}$, 1H), $7.13(\mathrm{t}, J=7.4 \mathrm{~Hz}, 1 \mathrm{H}), 7.09-7.02(\mathrm{~m}, 3 \mathrm{H}), 6.78(\mathrm{dd}, J=8.2,1.3 \mathrm{~Hz}, 1 \mathrm{H}), 4.82(\mathrm{~s}, 2 \mathrm{H})$. ${ }^{13} \mathrm{C}$ NMR (100 MHz, $\left.\mathrm{CDCl}_{3}\right): 158.5,156.7,138.5,135.0,133.2,131.9,130.7,129.9,129.5$, 124.5, 123.7, 121.6, 119.2, 114.3, 113.5, 109.4, 49.5. HRMS (ESI) calcd for $\mathrm{C}_{19} \mathrm{H}_{15} \mathrm{NNaO}_{3} \mathrm{~S}$ $[\mathrm{M}+\mathrm{Na}]^{+} 360.0665$, found 360.0655 . HPLC $t_{\mathrm{R}}=12.3 \mathrm{~min},>99.9 \%$.

2-(3-Phenoxyphenyl)isothiazolidine 1,1-dioxide (24). Step 1: To a solution of 3phenoxyaniline $(501 \mathrm{mg}, 2.71 \mathrm{mmol})$ in dry $\mathrm{CH}_{2} \mathrm{Cl}_{2}(10 \mathrm{~mL})$ was added pyridine $(0.57 \mathrm{~mL}, 7.02$ $\mathrm{mmol})$ and 3-chloropropanesulfonyl chloride $(0.4 \mathrm{~mL}, 3.24 \mathrm{mmol})$ at room temperature. The reaction was stirred for $16 \mathrm{~h}$, then diluted with $\mathrm{CH}_{2} \mathrm{Cl}_{2}$ and washed successively with $\mathrm{HCl}(1 \mathrm{~N}$, aq) and $\mathrm{NaHCO}_{3}$ (sat. aq.), dried $\left(\mathrm{Na}_{2} \mathrm{SO}_{4}\right)$ and concentrated to give 3-chloro- $N$-(3phenoxyphenyl)propane-1-sulfonamide as a crude yellow oil that was used directly in the next step. Step 2: To a solution of 3-chloro- $N$-(3-phenoxyphenyl)propane-1-sulfonamide in DMF (15 $\mathrm{mL})$ was added $\mathrm{K}_{2} \mathrm{CO}_{3}(963 \mathrm{mg}, 6.97 \mathrm{mmol})$ and stirred at $50{ }^{\circ} \mathrm{C}$ for $16 \mathrm{~h}$. The reaction mixture was cooled to room temperature, diluted with water and extracted with EtOAc (3x). The combined organic phases were washed with water and brine, dried $\left(\mathrm{Na}_{2} \mathrm{SO}_{4}\right)$ and concentrated. The crude was purified by flash chromatography (EtOAc:PE, 1:1) to give $\mathbf{2 4}$ as a pale yellow oil which solidified to an off-white solid after a week under high vacuum (596 mg, 72\% over two steps): ${ }^{1} \mathrm{H}$ NMR (400 MHz, $\left.\mathrm{CDCl}_{3}\right) \delta 7.37-7.27(\mathrm{~m}, 3 \mathrm{H}), 7.14-7.00(\mathrm{~m}, 4 \mathrm{H}), 6.88(\mathrm{t}, \mathrm{J}=2.2$ 
$\mathrm{Hz}, 1 \mathrm{H}), 6.74(\mathrm{dd}, \mathrm{J}=8.2,2.2 \mathrm{~Hz}, 1 \mathrm{H}), 3.74(\mathrm{t}, \mathrm{J}=6.5 \mathrm{~Hz}, 2 \mathrm{H}), 3.37$ (t, J = 7.5 Hz, 2H), 2.52 (p, $\mathrm{J}=7.0 \mathrm{~Hz}, 2 \mathrm{H}) ;{ }^{13} \mathrm{C} \mathrm{NMR}\left(100 \mathrm{MHz}, \mathrm{CDCl}_{3}\right) \delta 158.2,156.9,139.3,130.5,129.9,123.7,119.2$, 114.3, 113.9, 109.7, 48.5, 46.8, 18.8; HRMS (ESI) m/z: calculated $\mathrm{C}_{15} \mathrm{H}_{15} \mathrm{NNaO}_{3} \mathrm{~S}\left[\mathrm{M}+\mathrm{Na}^{+}\right]=$ 312.0665, found 312.0663. HPLC: $\mathrm{t}_{\mathrm{R}}=11.62 \mathrm{~min}, 99.5 \%$.

2-(3-Fluoro-5-hydroxyphenyl)-2,3-dihydrobenzo[d] isothiazole-1,1-dioxide (25). The title compound was obtained as described for 21 using 20 (500 mg, 3 mmol) and 3-bromo-5fluorophenol (677 mg, $3.55 \mathrm{mmol}$ ) as starting materials. The crude product was purified by flash chromatography (EtOAc/PE, 1:1) to give the desired compound $\mathbf{2 5}$ as a white solid (793 $\mathrm{mg}$, 96\%). ${ }^{1} \mathrm{H}$ NMR (400 MHz, DMSO-d $\left.)_{6}\right) 10.23$ (broad s, $\left.1 \mathrm{H}\right), 8.00$ (d, $\left.J=8.4 \mathrm{~Hz}, 1 \mathrm{H}\right), 7.82(\mathrm{dt}, J$ $=7.6,1.0 \mathrm{~Hz}, 1 \mathrm{H}), 7.71-7.67(\mathrm{~m}, 2 \mathrm{H}), 6.80(\mathrm{t}, J=1.9 \mathrm{~Hz}, 1 \mathrm{H}), 6.67(\mathrm{dt}, J=11.1,2.2 \mathrm{~Hz}, 1 \mathrm{H})$, $6.39(\mathrm{dt}, J=10.7,2.2 \mathrm{~Hz}, 1 \mathrm{H}), 5.04(\mathrm{~s}, 2 \mathrm{H}) .{ }^{13} \mathrm{C}$ NMR $\left(100 \mathrm{MHz}, \mathrm{DMSO}-d_{6}\right): 163.4(\mathrm{~d}, J=$ $240.6 \mathrm{~Hz}), 159.6(\mathrm{~d}, J=14.1 \mathrm{~Hz}), 139.2(\mathrm{~d}, J=13.9 \mathrm{~Hz}), 133.9,133.7,132.2,129.6,125.2$, 121.0, $101.0(\mathrm{~d}, J=2.4 \mathrm{~Hz}), 98.0(\mathrm{~d}, J=23.8 \mathrm{~Hz}), 95.9$ (d, $J=26.8 \mathrm{~Hz}) .49 .0$. HRMS (ESI) calcd for $\mathrm{C}_{13} \mathrm{H}_{10} \mathrm{FNNaO}_{3} \mathrm{~S}[\mathrm{M}+\mathrm{Na}]^{+}$302.0258, found 302.0256. HPLC $t_{\mathrm{R}}=10.3 \mathrm{~min}, 99.2 \%$. The spectra is in accordance with the literature. ${ }^{21}$

2-(3-Fluoro-5-(o-tolyloxy)phenyl)-2,3-dihydrobenzo[d] isothiazole-1,1-dioxide (26). The title compound was obtained as described for 22 using 25 (70 $\mathrm{mg}, 0.25 \mathrm{mmol})$ and 2bromotoluene ( $45 \mu \mathrm{L}, 0.38 \mathrm{mmol})$ as starting materials. The crude product was purified by flash chromatography (EtOAc/PE, 1:4) and recrystallized from EtOAc/PE (3:1) to give $\mathbf{2 6}$ as a white solid (23 mg, 25\%). ${ }^{1} \mathrm{H}$ NMR (400 MHz, $\left.\mathrm{CDCl}_{3}\right): 7.86(\mathrm{~d}, J=7.6 \mathrm{~Hz}, 1 \mathrm{H}), 7.68$ (t, $J=7.6 \mathrm{~Hz}$, 1H), 7.59 (t, $J=7.6 \mathrm{~Hz}, 1 \mathrm{H}), 7.49$ (d, $J=7.6 \mathrm{~Hz}, 1 \mathrm{H}), 7.28(\mathrm{~d}, J=7.6 \mathrm{~Hz}, 1 \mathrm{H}), 7.22$ (t, $J=7.6$ Hz, 1H), 7.14 (t, $J=7.6 \mathrm{~Hz}, 1 \mathrm{H}), 6.99$ (d, $J=7.6 \mathrm{~Hz}, 1 \mathrm{H}), 6.93$ (dt, $J=10.3,1.9 \mathrm{~Hz}, 1 \mathrm{H}), 6.81$ (s, 1H), $6.29(\mathrm{dt}, J=10.0,1.9 \mathrm{~Hz}, 1 \mathrm{H}), 4.80(\mathrm{~s}, 2 \mathrm{H}), 2.22(\mathrm{~s}, 3 \mathrm{H}) .{ }^{13} \mathrm{C} \mathrm{NMR}\left(100 \mathrm{MHz}, \mathrm{CDCl}_{3}\right)$ : 
$164.1(\mathrm{~d}, J=245.6 \mathrm{~Hz}), 160.3(\mathrm{~d}, J=12.8 \mathrm{~Hz}), 153.1,139.3(\mathrm{~d}, J=13.2 \mathrm{~Hz}), 134.8,133.4$, $131.8,131.5,130.4,129.6,127.5,125.2,124.5,121.6,120.6,102.5(\mathrm{~d}, J=2.9 \mathrm{~Hz}), 99.6(\mathrm{~d}, J=$ $25.5 \mathrm{~Hz}), 99.5(\mathrm{~d}, J=26.9 \mathrm{~Hz}), 49.3,16.1$. HRMS (ESI) calcd for $\mathrm{C}_{20} \mathrm{H}_{16} \mathrm{FNNaO}_{3} \mathrm{~S}[\mathrm{M}+\mathrm{Na}]^{+}$ 392.0727, found 392.0715. HPLC $t_{\mathrm{R}}=12.2 \mathrm{~min}, 99.2 \%$.

2-(3-Fluoro-5-(m-tolyloxy)phenyl)-2,3-dihydrobenzo[d]isothiazole-1,1-dioxide (27). The title compound was obtained as described for 22 using 25 (70 mg, 0.25 mmol) and 3-iodotoluene (48 $\mu \mathrm{L}, 0.38 \mathrm{mmol}$ ) as starting materials. The crude product was purified by flash chromatography (EtOAc/PE, 3:7) and recrystallized from EtOAc/PE (3:1) to give 27 as a white solid (33 mg, 36\%). ${ }^{1} \mathrm{H}$ NMR (400 MHz, $\left.\mathrm{CDCl}_{3}\right): 7.86(\mathrm{~d}, J=7.7 \mathrm{~Hz}, 1 \mathrm{H}), 7.68(\mathrm{t}, J=7.7 \mathrm{~Hz}$, 1H), 7.59 (t, $J=7.7 \mathrm{~Hz}, 1 \mathrm{H}), 7.48(\mathrm{~d}, J=7.7 \mathrm{~Hz}, 1 \mathrm{H}), 7.26(\mathrm{t}, J=7.7 \mathrm{~Hz}, 1 \mathrm{H}), 7.01-6.94(\mathrm{~m}$, 2H), $6.90-6.82(\mathrm{~m}, 3 \mathrm{H}), 6.42(\mathrm{dt}, J=9.8,2.0 \mathrm{~Hz}, 1 \mathrm{H}), 4.80(\mathrm{~s}, 2 \mathrm{H}), 2.36(\mathrm{~s}, 3 \mathrm{H}) .{ }^{13} \mathrm{C}$ NMR $(100$ $\left.\mathrm{MHz}, \mathrm{CDCl}_{3}\right): 164.0(\mathrm{~d}, J=245.8 \mathrm{~Hz}), 160.0(\mathrm{~d}, J=12.8 \mathrm{~Hz}), 155.7,140.3,139.3(\mathrm{~d}, J=13.1$ $\mathrm{Hz}), 134.8,133.4,131.5,129.7,129.6,125.3,124.5,121.6,120.4,116.8,103.8(\mathrm{~d}, J=2.9 \mathrm{~Hz})$, $101.0(\mathrm{~d}, J=25.1 \mathrm{~Hz}), 100.0(\mathrm{~d}, J=26.9 \mathrm{~Hz}), 49.3,21.4$. HRMS (ESI) calcd for $\mathrm{C}_{20} \mathrm{H}_{16} \mathrm{FNNaO}_{3} \mathrm{~S}[\mathrm{M}+\mathrm{Na}]^{+}$392.0727, found 392.0716. HPLC $t_{\mathrm{R}}=13.1 \mathrm{~min}, 99.4 \%$.

2-(3-Fluoro-5-(p-tolyloxy)phenyl)-2,3-dihydrobenzo $[d]$ isothiazole-1,1-dioxide (28). The title compound was obtained as described for 22 using 25 (70 mg, $0.25 \mathrm{mmol}$ ) and 4-iodotoluene (82 $\mathrm{mg}, 0.38 \mathrm{mmol}$ ) as starting materials. The crude product was purified by flash chromatography (EtOAc/PE, 3:7) and recrystallized from EtOAc/PE (3:1) to give 28 as a white solid (24 mg, 26\%). ${ }^{1} \mathrm{H}$ NMR (400 MHz, $\left.\mathrm{CDCl}_{3}\right): 7.87$ (d, $\left.J=7.7 \mathrm{~Hz}, 1 \mathrm{H}\right), 7.68$ (td, $J=7.7,0.8$ $\mathrm{Hz}, 1 \mathrm{H}), 7.60$ (t, $J=7.7 \mathrm{~Hz}, 1 \mathrm{H}), 7.49$ (d, $J=7.7 \mathrm{~Hz}, 1 \mathrm{H}), 7.19$ (d, $J=8.2 \mathrm{~Hz}, 2 \mathrm{H}), 7.00-6.92$ $(\mathrm{m}, 3 \mathrm{H}), 6.84(\mathrm{~s}, 1 \mathrm{H}), 6.41(\mathrm{dt}, J=9.9,2.0 \mathrm{~Hz}, 1 \mathrm{H}), 4.80(\mathrm{~s}, 2 \mathrm{H}), 2.36(\mathrm{~s}, 3 \mathrm{H}) .{ }^{13} \mathrm{C}$ NMR $(100$ $\left.\mathrm{MHz}, \mathrm{CDCl}_{3}\right): 164.0(\mathrm{~d}, J=245.7 \mathrm{~Hz}), 160.4(\mathrm{~d}, J=12.6 \mathrm{~Hz}), 153.2,139.3(\mathrm{~d}, J=13.2 \mathrm{~Hz})$, 
134.8, 134.2, 133.4, 131.5, 130.5, 129.6, 124.5, 121.6, 119.9, 103.4 (d, $J=3.0 \mathrm{~Hz}), 100.7$ (d, $J=$ $25.3 \mathrm{~Hz}$ ), $99.9\left(\mathrm{~d}, J=27.0 \mathrm{~Hz}\right.$ ), 49.3, 20.8. HRMS (ESI) calcd for $\mathrm{C}_{20} \mathrm{H}_{16} \mathrm{FNNaO}_{3} \mathrm{~S}[\mathrm{M}+\mathrm{Na}]^{+}$ 392.0727, found 392.0714. HPLC $t_{\mathrm{R}}=13.1 \mathrm{~min}, 99.7 \%$.

2-(3-(1,1-Dioxidobenzo $[d]$ isothiazol-2(3H)-yl)-5-fluorophenoxy)benzonitrile (29). The title compound was obtained as described for 22 using 25 (79 $\mathrm{mg}, 0.28 \mathrm{mmol}$ ) and 2bromobenzonitrile (40 $\mathrm{mg}, 0.22 \mathrm{mmol}$ ) as starting materials. The crude product was purified by flash chromatography (EtOAc/PE, 1:4) and the title compound 29 was recrystallized from EtOAc/PE (3:1) as a white solid (10 mg, 12\%). ${ }^{1} \mathrm{H}$ NMR (400 MHz, $\left.\mathrm{CDCl}_{3}\right): 7.88(\mathrm{~d}, J=7.7 \mathrm{~Hz}$, 1H), 7.73-7.69 (m, 2H), $7.62(\mathrm{t}, J=7.7 \mathrm{~Hz}, 1 \mathrm{H}), 7.57(\mathrm{td}, J=7.7,1.6 \mathrm{~Hz}, 1 \mathrm{H}), 7.51(\mathrm{~d}, J=7.7$ $\mathrm{Hz}, 1 \mathrm{H}), 7.23(\mathrm{t}, J=7.6 \mathrm{~Hz}, 1 \mathrm{H}), 7.09$ (dt, $J=10.2,2.0 \mathrm{~Hz}, 1 \mathrm{H}), 7.05(\mathrm{~d}, J=8.5 \mathrm{~Hz}, 1 \mathrm{H}), 6.96$ $(\mathrm{s}, 1 \mathrm{H}), 6.55(\mathrm{dt}, J=9.1,2.0 \mathrm{~Hz}, 1 \mathrm{H}), 4.85(\mathrm{~s}, 2 \mathrm{H}) .{ }^{13} \mathrm{C} \mathrm{NMR}\left(100 \mathrm{MHz}, \mathrm{CDCl}_{3}\right): 164.0(\mathrm{~d}, J=$ $247.8 \mathrm{~Hz}), 158.2,157.3(\mathrm{~d}, J=12.9 \mathrm{~Hz}), 139.9(\mathrm{~d}, J=12.7 \mathrm{~Hz}), 134.6,134.5,134.1,133.6$, $131.2,129.8,124.5,124.1,121.6,118.2,115.5,104.8(\mathrm{~d}, J=3.2 \mathrm{~Hz}), 104.7,102.4(\mathrm{~d}, J=25.3$ $\mathrm{Hz}), 101.8(\mathrm{~d}, J=26.6 \mathrm{~Hz}) .49 .3$. HRMS (ESI) calcd for $\mathrm{C}_{20} \mathrm{H}_{13} \mathrm{FN}_{2} \mathrm{NaO}_{3} \mathrm{~S}[\mathrm{M}+\mathrm{Na}]^{+}$403.0523, found 403.0528. HPLC $t_{\mathrm{R}}=11.9 \mathrm{~min}, 99.5 \%$.

3-(3-(1,1-Dioxidobenzo[d] isothiazol-2(3H)-yl)-5-fluorophenoxy)benzonitrile (30). The title compound was obtained as described for 22 using 25 (58 mg, $0.21 \mathrm{mmol})$ and 3-iodobenzonitrile (40 mg, $0.17 \mathrm{mmol}$ ) as starting materials. The crude product was purified by flash chromatography (EtOAc/PE, 3:7) and recrystallized from EtOAc/PE (3:1) to give 30 as a white solid (20 mg, 30\%). ${ }^{1} \mathrm{H}$ NMR (400 MHz, $\left.\mathrm{CDCl}_{3}\right): 7.88(\mathrm{~d}, J=7.8 \mathrm{~Hz}, 1 \mathrm{H}), 7.71(\mathrm{t}, J=7.5 \mathrm{~Hz}$, 1H), $7.62(\mathrm{t}, J=7.5 \mathrm{~Hz}, 1 \mathrm{H}), 7.53-7.43(\mathrm{~m}, 3 \mathrm{H}), 7.35-7.28(\mathrm{~m}, 2 \mathrm{H}), 7.00(\mathrm{dt}, J=10.2,2.0$ $\mathrm{Hz}, 1 \mathrm{H}), 6.95(\mathrm{~s}, 1 \mathrm{H}), 6.48(\mathrm{dt}, J=9.3,2.0 \mathrm{~Hz}, 1 \mathrm{H}), 4.84(\mathrm{~s}, 2 \mathrm{H}) .{ }^{13} \mathrm{C} \mathrm{NMR}\left(100 \mathrm{MHz}, \mathrm{CDCl}_{3}\right)$ : $164.1(\mathrm{~d}, J=247.5 \mathrm{~Hz}), 158.0(\mathrm{~d}, J=12.7 \mathrm{~Hz}), 156.7,139.9(\mathrm{~d}, J=12.8 \mathrm{~Hz}), 134.6,133.6$, 
131.2, 131.0, 129.8, 127.7, 124.5, 123.6, 122.2, 121.6, 118.0, 114.0, $104.5(\mathrm{~d}, J=3.1 \mathrm{~Hz}), 101.9$ (d, $J=25.0 \mathrm{~Hz}), 101.2(\mathrm{~d}, J=26.9 \mathrm{~Hz})$, 49.2. $\mathrm{HRMS}(\mathrm{ESI})$ calcd for $\mathrm{C}_{20} \mathrm{H}_{13} \mathrm{FN}_{2} \mathrm{NaO}_{3} \mathrm{~S}[\mathrm{M}+\mathrm{Na}]^{+}$ 403.0523, found 403.0523. HPLC $t_{\mathrm{R}}=12.2 \mathrm{~min}, 98.6 \%$.

4-(3-(1,1-Dioxidobenzo[d] isothiazol-2(3H)-yl)-5-fluorophenoxy)benzonitrile (31). The title compound was obtained as described for 22 using 25 (74 $\mathrm{mg}, 0.26 \mathrm{mmol}$ ) and 4bromobenzonitrile (40 mg, $0.22 \mathrm{mmol}$ ) as starting materials. The crude product was purified by flash chromatography (EtOAc/PE, 1:3) and recrystallized from EtOAc/PE (3:1) to give 31 as a white solid (37 mg, 45\%). ${ }^{1} \mathrm{H}$ NMR (400 MHz, $\left.\mathrm{CDCl}_{3}\right): 7.88(\mathrm{~d}, J=7.7 \mathrm{~Hz}, 1 \mathrm{H}), 7.71(\mathrm{t}, J=7.7$ $\mathrm{Hz}, 1 \mathrm{H}), 7.66(\mathrm{~d}, J=8.8 \mathrm{~Hz}, 2 \mathrm{H}), 7.63(\mathrm{t}, J=7.7 \mathrm{~Hz}, 1 \mathrm{H}), 7.51(\mathrm{~d}, J=7.7 \mathrm{~Hz}, 1 \mathrm{H}), 7.11(\mathrm{~d}, J=$ $8.8 \mathrm{~Hz}, 2 \mathrm{H}), 7.03(\mathrm{dt}, J=10.2,2.0 \mathrm{~Hz}, 1 \mathrm{H}), 6.97(\mathrm{~s}, 1 \mathrm{H}), 6.55(\mathrm{dt}, J=9.1,2.0 \mathrm{~Hz}, 1 \mathrm{H}), 4.84(\mathrm{~s}$, 2H). ${ }^{13} \mathrm{C} \mathrm{NMR}\left(100 \mathrm{MHz}, \mathrm{CDCl}_{3}\right): 164.1(\mathrm{~d}, J=248.0 \mathrm{~Hz}), 160.2,157.2(\mathrm{~d}, J=12.9 \mathrm{~Hz}), 140.0$ $(\mathrm{d}, J=12.8 \mathrm{~Hz}), 134.6,134.4,133.6,131.2,129.8,124.5,121.7,118.8,118.5,107.2,105.1(\mathrm{~d}, J$ $=3.1 \mathrm{~Hz}), 102.8(\mathrm{~d}, J=24.8 \mathrm{~Hz}), 101.6(\mathrm{~d}, J=26.7 \mathrm{~Hz}), 49.2$. HRMS (ESI) calcd for $\mathrm{C}_{20} \mathrm{H}_{13} \mathrm{FN}_{2} \mathrm{NaO}_{3} \mathrm{~S}[\mathrm{M}+\mathrm{Na}]^{+}$403.0523, found 403.0503. HPLC $t_{\mathrm{R}}=12.2 \mathrm{~min}, 99.2 \%$.

\section{2-(3-(3-(1,1-Dioxidobenzo[d] isothiazol-2(3H)-yl)-5-fluorophenoxy)phenyl)acetonitrile}

(32). The title compound was obtained as described for 22 using 25 (70 $\mathrm{mg}, 0.25 \mathrm{mmol}$ ) and 3bromophenylacetonitrile $(40 \mathrm{mg}, 0.38 \mathrm{mmol})$ as starting materials. The crude product was purified by flash chromatography (EtOAc/PE, 3:7) and the title compound 32 was recrystallized from EtOAc/PE (3:1) as an orange solid (20 mg, 20\%). ${ }^{1} \mathrm{H} \mathrm{NMR}\left(400 \mathrm{MHz}, \mathrm{CDCl}_{3}\right): 7.86(\mathrm{~d}, J=$ $7.7 \mathrm{~Hz}, 1 \mathrm{H}), 7.69(\mathrm{td}, J=7.7,1.0 \mathrm{~Hz}, 1 \mathrm{H}), 7.61(\mathrm{t}, J=7.7 \mathrm{~Hz}, 1 \mathrm{H}), 7.50(\mathrm{~d}, J=7.7 \mathrm{~Hz}, 1 \mathrm{H}), 7.40$ $(\mathrm{td}, J=1.6,7.6 \mathrm{~Hz}, 1 \mathrm{H}), 7.16(\mathrm{~d}, J=8.0 \mathrm{~Hz}, 1 \mathrm{H}), 7.06-7.02(\mathrm{~m}, 2 \mathrm{H}), 6.99(\mathrm{dt}, J=10.2,2.1 \mathrm{~Hz}$, 1H), $6.89(\mathrm{~s}, 1 \mathrm{H}), 6.46(\mathrm{dt}, J=9.6,2.1 \mathrm{~Hz}, 1 \mathrm{H}), 4.82(\mathrm{~s}, 2 \mathrm{H}), 3.76(\mathrm{~s}, 2 \mathrm{H}) .{ }^{13} \mathrm{C} \mathrm{NMR}(100 \mathrm{MHz}$, $\left.\mathrm{CDCl}_{3}\right): 164.0(\mathrm{~d}, J=246.6), 159.0(\mathrm{~d}, J=12.8), 156.6,139.5(\mathrm{~d}, J=13.2), 134.7,133.5,132.1$, 
$131.4,130.8,129.7,124.5,123.7,121.6,119.09,119.08,117.5,104.0(\mathrm{~d}, J=3.1), 101.5(\mathrm{~d}, J=$ 25.0), $100.6\left(\mathrm{~d}, J=26.8\right.$ ), 49.3, 23.5. HRMS (ESI) calcd for $\mathrm{C}_{21} \mathrm{H}_{15} \mathrm{FN}_{2} \mathrm{NaO}_{3} \mathrm{~S}[\mathrm{M}+\mathrm{Na}]^{+}$ 417.0680, found 417.0667. HPLC $t_{\mathrm{R}}=12.0 \mathrm{~min}, 99.5 \%$.

\section{2-(3-Fluoro-5-(pyridin-4-yloxy)phenyl)-2,3-dihydrobenzo[d]isothiazole-1,1-dioxide $\quad$ (33).}

The title compound was obtained as described for 22 using 25 (79 mg, $0.28 \mathrm{mmol}$ ) and 4bromopyridine hydrochloride ( $46 \mathrm{mg}, 0.22 \mathrm{mmol}$ ) as starting materials. The crude product was purified by flash chromatography (EtOAc/PE, 9:1) to provide $\mathbf{3 3}$ as a white solid (34 $\mathrm{mg}, 40 \%$ ). ${ }^{1} \mathrm{H}$ NMR (400 MHz, $\left.\mathrm{CDCl}_{3}\right): 8.54$ (d, $\left.J=3.9 \mathrm{~Hz}, 2 \mathrm{H}\right), 7.88(\mathrm{~d}, J=7.8 \mathrm{~Hz}, 1 \mathrm{H}), 7.71$ (t, $J=7.5$ Hz, 1H), 7.62 (t, $J=7.6 \mathrm{~Hz}, 1 \mathrm{H}), 7.51(\mathrm{~d}, J=7.7 \mathrm{~Hz}, 1 \mathrm{H}), 7.10(\mathrm{~d}, J=10.2 \mathrm{~Hz}, 1 \mathrm{H}), 6.97$ (s, $1 \mathrm{H}), 6.93(\mathrm{~d}, J=5.5 \mathrm{~Hz}, 2 \mathrm{H}), 6.61(\mathrm{~d}, J=9.0 \mathrm{~Hz}, 1 \mathrm{H}), 4.84(\mathrm{~s}, 2 \mathrm{H}) .{ }^{13} \mathrm{C}$ NMR $(100 \mathrm{MHz}$, $\left.\mathrm{CDCl}_{3}\right): 164.0(\mathrm{~d}, J=248.0), 163.6,156.2(\mathrm{~d}, J=12.9), 151.7,139.9(\mathrm{~d}, J=12.9), 134.6,133.6$, $131.2,129.8,124.6,121.6,112.7,105.5(\mathrm{~d}, J=3.2), 103.4(\mathrm{~d}, J=24.5), 102.0(\mathrm{~d}, J=26.7)$, 49.3. HRMS (ESI) calcd for $\mathrm{C}_{18} \mathrm{H}_{14} \mathrm{FN}_{2} \mathrm{O}_{3} \mathrm{~S}[\mathrm{M}+\mathrm{H}]^{+}$357.0704, found 357.0717. HPLC $t_{\mathrm{R}}=8.6$ $\min , 98.8 \%$.

\section{2-(3-Fluoro-5-(pyridin-2-yloxy)phenyl)-2,3-dihydrobenzo[d] isothiazole-1,1-dioxide}

(34).

The title compound was obtained as described for 22 using 25 (75 mg, $0.27 \mathrm{mmol})$ and 2iodopyridine ( $24 \mu \mathrm{L}, 0.22 \mathrm{mmol})$ as starting materials. The crude product was purified by flash chromatography (EtOAc/PE, 2:3) and the title compound $\mathbf{3 4}$ was recrystallized from acetone/PE as a white solid (36 mg, 45\%). ${ }^{1} \mathrm{H}$ NMR (400 MHz, $\left.\mathrm{CDCl}_{3}\right): 8.23$ (dd, $\left.J=4.7,1.4 \mathrm{~Hz}, 1 \mathrm{H}\right), 7.86$ $(\mathrm{d}, J=7.6 \mathrm{~Hz}, 1 \mathrm{H}), 7.73(\mathrm{dd}, J=7.6,1.9 \mathrm{~Hz}, 1 \mathrm{H}), 7.68(\mathrm{t}, J=7.6 \mathrm{~Hz}, 1 \mathrm{H}), 7.59(\mathrm{t}, J=7.6 \mathrm{~Hz}$ 1H), $7.49(\mathrm{~d}, J=7.6 \mathrm{~Hz}, 1 \mathrm{H}), 7.08-7.04(\mathrm{~m}, 2 \mathrm{H}), 7.01(\mathrm{~s}, 1 \mathrm{H}), 6.97$ (d, $J=8.3 \mathrm{~Hz}, 1 \mathrm{H}), 6.69$ (dt, $J=9.4,1.8 \mathrm{~Hz}, 1 \mathrm{H}), 4.83(\mathrm{~s}, 2 \mathrm{H}) \cdot{ }^{13} \mathrm{C} \mathrm{NMR}\left(100 \mathrm{MHz}, \mathrm{CDCl}_{3}\right): 163.7$ (d, $\left.J=246.3 \mathrm{~Hz}\right)$, 162.7, $156.2(\mathrm{~d}, J=13.3 \mathrm{~Hz}), 147.8,139.8,139.2(\mathrm{~d}, J=12.8 \mathrm{~Hz}), 134.8,133.4,131.4,129.6$, 
124.5, 121.6, 119.4, 112.1, 106.5 (d, $J=3.2 \mathrm{~Hz}), 104.3(\mathrm{~d}, J=24.5 \mathrm{~Hz}), 101.8(\mathrm{~d}, J=26.7 \mathrm{~Hz})$, 49.3. HRMS (ESI) calcd for $\mathrm{C}_{18} \mathrm{H}_{14} \mathrm{FN}_{2} \mathrm{O}_{3} \mathrm{~S}[\mathrm{M}+\mathrm{H}]^{+}$357.0704, found 357.0704. HPLC $t_{\mathrm{R}}=11.6$ $\min , 98.1 \%$.

2-(3-Iodophenoxy)pyridine (35). A vial was charged with 3-iodophenol (500 mg, 2.27 $\mathrm{mmol}$ ), $\mathrm{K}_{2} \mathrm{CO}_{3}(345 \mathrm{mg}, 2.5 \mathrm{mmol})$, dry DMF (2 mL) and 2-fluoropyridine (196 $\mu \mathrm{L}, 2.27$ mmol). The vial was capped and heated at $140{ }^{\circ} \mathrm{C}$ under microwave irradiation for $6 \mathrm{~h}$. The reaction was partitioned between water and EtOAc, the aqueous phase was extracted with EtOAc (2x). The combined organic phases were washed with brine, dried $\left(\mathrm{Na}_{2} \mathrm{SO}_{4}\right)$ and concentrated. The crude product was purified by flash chromatography (EtOAc/PE, 1:9) to give 35 as colorless oil that solidified upon standing (416 mg, 62\%). ${ }^{1} \mathrm{H}$ NMR (400 MHz, $\left.\mathrm{CDCl}_{3}\right): 8.20(\mathrm{dd}, J=4.9$, $1.3 \mathrm{~Hz}, 1 \mathrm{H}), 7.70(\mathrm{td}, J=8.3,1.9 \mathrm{~Hz}, 1 \mathrm{H}), 7.55-7.48(\mathrm{~m}, 2 \mathrm{H}), 7.16-7.09(\mathrm{~m}, 2 \mathrm{H}), 7.02(\mathrm{dd}, J$ $=6.8,5.4 \mathrm{~Hz}, 1 \mathrm{H}), 6.92(\mathrm{~d}, J=8.3 \mathrm{~Hz}, 1 \mathrm{H}) .{ }^{13} \mathrm{C} \mathrm{NMR}\left(100 \mathrm{MHz}, \mathrm{CDCl}_{3}\right): 163.2,154.6,147.8$, 139.6, 133.7, 130.9, 130.3, 120.7, 119.0, 111.8, 94.0. HRMS (ESI) calcd for $\mathrm{C}_{11} \mathrm{H}_{9} \mathrm{INO}[\mathrm{M}+\mathrm{H}]^{+}$ 297.9723, found 297.9716. HPLC $t_{\mathrm{R}}=12.5 \mathrm{~min}, 99.8 \%$.

2-(3-(Pyridin-2-yloxy)phenyl)-2,3-dihydrobenzo[d] isothiazole-1,1-dioxide (36). The title compound was obtained as described for 21 using 20 (75 mg, $0.44 \mathrm{mmol})$ and 35 (158 $\mathrm{mg}, 0.53$ mmol) as starting materials. The crude product was purified by flash chromatography (EtOAc/PE, 1:1) and the title compound (36) was recrystallized from EtOAc/PE (1:1) as a white solid (110 mg, 73\%). ${ }^{1} \mathrm{H}$ NMR (400 MHz, $\left.\mathrm{CDCl}_{3}\right): 8.21(\mathrm{dd}, J=5.0,1.3 \mathrm{~Hz}, 1 \mathrm{H}), 7.86(\mathrm{~d}, J=$ $7.5 \mathrm{~Hz}, 1 \mathrm{H}), 7.70(\mathrm{ddd}, J=8.3,7.4,2.0 \mathrm{~Hz}, 1 \mathrm{H}), 7.65(\mathrm{td}, J=0.8,7.5 \mathrm{~Hz}, 1 \mathrm{H}), 7.58(\mathrm{t}, J=7.5$ $\mathrm{Hz}, 1 \mathrm{H}), 7.48(\mathrm{~d}, J=7.5 \mathrm{~Hz}, 1 \mathrm{H}), 7.43(\mathrm{t}, J=8.1 \mathrm{~Hz}, 1 \mathrm{H}), 7.36(\mathrm{dd}, J=8.2,1.3 \mathrm{~Hz}, 1 \mathrm{H}), 7.21(\mathrm{t}$, $J=2.1 \mathrm{~Hz}, 1 \mathrm{H}), 7.01(\mathrm{ddd}, J=6.9,5.0,0.6 \mathrm{~Hz}, 1 \mathrm{H}), 6.98-6.92(\mathrm{~m}, 2 \mathrm{H}), 4.85(\mathrm{~s}, 2 \mathrm{H}) .{ }^{13} \mathrm{C} \mathrm{NMR}$ $\left(100 \mathrm{MHz}, \mathrm{CDCl}_{3}\right): 163.4,155.2,147.8,139.6,138.4,135.0,133.2,131.9,130.6,129.5,124.5$, 
121.5, 118.8, 117.0, 115.0, 111.9, 111.8, 49.5. HRMS (ESI) calcd for $\mathrm{C}_{18} \mathrm{H}_{15} \mathrm{~N}_{2} \mathrm{O}_{3} \mathrm{~S}[\mathrm{M}+\mathrm{H}]^{+}$ 339.0798, found 339.0787. HPLC $t_{\mathrm{R}}=11.2 \mathrm{~min}, 99.6 \%$.

2-(3-Bromo-5-chlorophenoxy)pyridine (37). The title compound was obtained as described for 35 using 3-bromo-5-chlorophenol (100 mg, $0.48 \mathrm{mmol})$ and 2-fluoropyridine (41 $\mu \mathrm{L}, 0.48$ mmol) as starting materials. The crude product was purified by flash chromatography (EtOAc/PE, 1:9) to give 37 as colorless oil that crystallized upon standing $(89 \mathrm{mg}, 65 \%) .{ }^{1} \mathrm{H}$ NMR (400 MHz, $\left.\mathrm{CDCl}_{3}\right): 8.21(\mathrm{ddd}, J=5.0,2.0,0.7 \mathrm{~Hz}, 1 \mathrm{H}), 7.74(\mathrm{ddd}, J=8.3,7.2,2.0 \mathrm{~Hz}$, 1H), $7.34(\mathrm{t}, J=1.9 \mathrm{~Hz}, 1 \mathrm{H}), 7.22(\mathrm{t}, J=1.9 \mathrm{~Hz}, 1 \mathrm{H}), 7.11(\mathrm{t}, J=1.9 \mathrm{~Hz}, 1 \mathrm{H}), 7.07$ (ddd, $J=7.2$, 5.0, $0.7 \mathrm{~Hz}, 1 \mathrm{H}), 6.96(\mathrm{dt}, J=8.3,0.7 \mathrm{~Hz}, 1 \mathrm{H}) .{ }^{13} \mathrm{C} \mathrm{NMR}\left(100 \mathrm{MHz}, \mathrm{CDCl}_{3}\right): 162.5,155.2$, $147.7,139.8,135.5,127.6,122.9,122.7,120.5,119.5,112.1$. HRMS (ESI) calcd for $\mathrm{C}_{11} \mathrm{H}_{8} \mathrm{BrClNO}[\mathrm{M}+\mathrm{H}]^{+}$283.9472, found 283.9483. HPLC $t_{\mathrm{R}}=13.4 \mathrm{~min}, 98.9 \%$.

\section{2-(3-Chloro-5-(pyridin-2-yloxy)phenyl)-2,3-dihydrobenzo[d] isothiazole-1,1-dioxide (38).}

The title compound was obtained as described for 21 using 20 (37 mg, $0.22 \mathrm{mmol})$ and 37 (75 $\mathrm{mg}, 0.26 \mathrm{mmol}$ ) as starting materials. The crude product was purified by flash chromatography (EtOAc/PE, 3:7) to provide 38 as a colorless oil that crystallized upon standing $(50 \mathrm{mg}, 61 \%) .{ }^{1} \mathrm{H}$ NMR (400 MHz, $\left.\mathrm{CDCl}_{3}\right): 8.22(\mathrm{ddd}, J=5.0,1.9,0.6 \mathrm{~Hz}, 1 \mathrm{H}), 7.87(\mathrm{~d}, J=7.6 \mathrm{~Hz}, 1 \mathrm{H}), 7.73$ $(\mathrm{ddd}, J=8.3,7.2,2.0 \mathrm{~Hz}, 1 \mathrm{H}), 7.69(\mathrm{td}, J=7.6,1.1 \mathrm{~Hz}, 1 \mathrm{H}), 7.60(\mathrm{t}, J=7.6 \mathrm{~Hz}, 1 \mathrm{H}), 7.49(\mathrm{~d}, \mathrm{~J}$ $=7.6 \mathrm{~Hz}, 1 \mathrm{H}), 7.29(\mathrm{t}, J=2.0 \mathrm{~Hz}, 1 \mathrm{H}), 7.17(\mathrm{t}, J=2.0 \mathrm{~Hz}, 1 \mathrm{H}), 7.06(\mathrm{ddd}, J=7.2,5.0,0.9 \mathrm{~Hz}$, 1H), $7.00-6.95(\mathrm{~m}, 2 \mathrm{H}), 4.85(\mathrm{~s}, 2 \mathrm{H}) .{ }^{13} \mathrm{C} \mathrm{NMR}\left(100 \mathrm{MHz}, \mathrm{CDCl}_{3}\right): 162.8,155.6,147.8,139.8$, $139.1,135.9,134.8,133.4,131.5,129.6,124.49,121.6,119.3,117.2,114.5,112.1,109.7,49.4$. HRMS (ESI) calcd for $\mathrm{C}_{18} \mathrm{H}_{14} \mathrm{ClNO}_{3} \mathrm{~S}[\mathrm{M}+\mathrm{H}]^{+}$373.0408, found 374.0406. HPLC $t_{\mathrm{R}}=12.1 \mathrm{~min}$, $>99.9 \%$.

\section{Computational modeling}


Homology modeling. The sequences of the short isoform of human FFA4 and the nanobodystabilized $\beta_{2}$-adrenoceptor (PDB ID 3P0G) ${ }^{31}$ were aligned manually. Homology models of FFA4 were constructed using Modeller 9.14. ${ }^{32}$ The FFA4 homology model was imported into Maestro, ${ }^{33}$ preprocessed using the OPLS-2005 force field, added hydrogen atoms and assigned partial charges. Hydrogen bond assignment was done at $\mathrm{pH}=7.4$ using PROPKA. ${ }^{34}$ Restrained minimization was performed until heavy atoms converged to RMSD $=0.3 \AA$ using the OPLS2005 force field.

Ligand Preparation and Docking. All ligands were converted to three-dimensional structures in Maestro. MacroModel was used for energy minimization of ligands using the OPLS-2005 force field. ${ }^{35}$ Ligands were prepared using Lig-Prep. ${ }^{36}$ Ionization states were generated using Epik at $\mathrm{pH} 7.0 \pm 1.0$, and low energy ring conformations were restricted to one per ligand. Induced-fit docking studies were performed using the extended sampling protocol as implemented in Schrodinger suite 2015-3. ${ }^{37}$ Ligand conformational sampling was performed using default settings. Prime was used to refine residues within $5.0 \AA$ of ligand poses. ${ }^{38}$

\section{In vitro assays}

及-Arrestin-2 Interaction Assay. Plasmids encoding human or mouse FFA4 or human or mouse FFA1 fused at the C-terminal to enhanced yellow fluorescent protein were cotransfected into HEK 293 cells with a plasmid encoding $\beta$-arrestin-2 fused to Renilla luciferase. Cells were distributed into white 96-well plates $24 \mathrm{~h}$ post-transfection and then maintained in culture for another $24 \mathrm{~h}$ prior to their use. For FFA4, the cells were first washed in Hank's Balanced Salt Solution and then the Renilla luciferase substrate coelenterazine $\mathrm{h}(2.5 \mu \mathrm{M})$ for 15 mins. For the final 5 mins of coelentrazine $\mathrm{h}$ incubation, the cells were treated with the ligands of interest. For FFA1, following cell washing, the cells were firstly incubated with ligands for 30 mins. 15 mins 
prior to the end of the incubation, the cells were treated with coelentrazine $\mathrm{h}(2.5 \mu \mathrm{M})$. All incubations were at $37^{\circ} \mathrm{C}$. Test ligands for FFA1 and FFA4 were dissolved in DMSO and then diluted in HBSS, resulting in a final DMSO concentration within the assay of $1 \%$. Luminescence at 535 and $475 \mathrm{~nm}$ was then measured using a Pherastar FS plate reader and the ratio of luminescence at 535/475 $\mathrm{nm}$ used to calculate the BRET response.

FFA1 Calcium Mobilization Assay. 1321N1 cells stably transfected with human FFA1 were grown in Dulbecco's modified Eagle's medium supplemented with 10\% (v/v) fetal calf serum, $100 \mathrm{U} / \mathrm{mL}$ penicillin, $100 \mu \mathrm{g} / \mathrm{mL}$ streptomycin, and $400 \mu \mathrm{g} / \mathrm{mL}$ G418. Cells were seeded in 96well black clear-bottom microplates at a density of 15,000 cells per well. After $24 \mathrm{~h}$, the cells were incubated in culture medium containing the $\mathrm{Ca}^{2+}$-sensitive dye Fura2-AM (3 mM) for 45 min. Cells were then washed three times in Hanks' balanced salt solution (HBSS) and then allowed to equilibrate for 15 mins before conducting the assay. Test ligands dissolved in DMSO were diluted in HBSS and then added to the Fura2-AM-containing cells by the Flexstation, resulting in a final DMSO concentration within the assay of 1\%. Fura2 fluorescent emission was then measured at $510 \mathrm{~nm}$ following excitation at both 340 and $380 \mathrm{~nm}$ during the course of the experiment using a Flexstation plate reader (Molecular Devices). $\mathrm{Ca}^{2+}$ responses were measured as the difference between 340:380 ratios before and after the addition of ligands. For antagonism testing, $\mathrm{Ca}^{2+}$ assays were carried out on Flp-In T-REx 293 cell lines, generated to inducibly express FFA1 upon treatment with doxycycline. One day prior to conducting the experiment, cells were seeded at 50000 cells/well and allowed to adhere for 3-4 h before the addition of 100 $\mathrm{ng} / \mathrm{ml}$ doxycycline to induce receptor expression. The following day, cells were incubated in culture medium containing Fura2-AM (3 mM) for $45 \mathrm{~min}$. Cells were then washed three times and then preincubated for 15 min in Hanks' balanced salt solution (HBSS) supplemented with 
the appropriate ligands to be tested for antagonism. Upon addition of $300 \mathrm{nM} \mathbf{1 0}$, Fura2 fluorescent emission and subsequent $\mathrm{Ca}^{2+}$ responses were measured as described above.

FFA4 Calcium Mobilization Assay. $\mathrm{Ca}^{2+}$ assays were carried out on Flp-In T-REx 293 cell lines, generated to inducibly express FFA4 upon treatment with doxycycline. As described above, 24 hours prior to conducting the experiment, cells were seeded at 50000 cells/well in black clear-bottom 96-well microplates, allowed to adhere, and then treated with $100 \mathrm{ng} / \mathrm{ml}$ doxycycline overnight to induce receptor expression. The following day, cells were incubated in culture medium containing Fura2-AM (3 mM) for $45 \mathrm{~min}$, washed three times in HBSS, and then allowed to equilibrate for $15 \mathrm{~min}$. Test ligands dissolved in DMSO were diluted in HBSS and then added to the Fura2-AM-containing cells by the Flexstation, resulting in a final DMSO concentration within the assay of $1 \%$. Upon ligand addition, Fura2 fluorescent emission and $\mathrm{Ca}^{2+}$ responses were then measured as described above.

Data Analysis. BRET and $\mathrm{Ca}^{2+}$ data is presented as the means \pm S.E. of 2-4 independent experiments, with all data analysis and curve fitting carried out using three parameter sigmoidal concentration-response curves generated from the GraphPad Prism software package version 5.0b (GraphPad, San Diego).

\section{Animal studies}

Male wild-type mice were obtained from Charles Rivers (Maidstone, Kent, UK). Mice were received at five weeks of age. FFA4 (Taconic) knockout mice on a C57B16 background were maintained in house and were over more than 8 generations crossed to the B16 background. They were fed on standard laboratory chow (Beekay Feed; B\&K Universal Ltd., Hull, UK) until used, except that for the studies on diet-induced obesity when FFA4(-/-) mice and wild-type littermates were fed from the age of 6 weeks on a high-fat (63\% by energy; Open Source D12492, Research 
Diets, New Brunswick, NJ, USA) for 5 months. The bodyweights of the genotypes at the onset of dosing (day 0) were $47.1 \pm 3.1 \mathrm{~g}$ for wild-type mice and $46.0 \pm 3.8 \mathrm{~g}$ the FFA4(-/-) mice. Housing and procedures were conducted in accordance with the UK Government Animal (Scientific procedures) Act 1986 and approved by the University of Buckingham Ethical review Board. Animals were housed in cages of three on a 12 hour light: dark cycle from 7:00 to 19:00 at $25-26{ }^{\circ} \mathrm{C}$ with ad libitum access to food and water. Animals were killed $3-4 \mathrm{~h}$ after the onset of the light cycle, by a UK Government Animal Scientific Act 1986 schedule 1 method.

Oral glucose tolerance. Oral glucose tolerance was measured as described previously. ${ }^{39}$ Briefly, mice were fasted for five $\mathrm{h}$ before being dosed with glucose ( $3 \mathrm{~g} / \mathrm{kg}$ bodyweight, po). Blood samples $(10 \mu \mathrm{L})$ were taken from the tip of the tail after applying a local anesthetic (Lignocaine $^{\mathrm{TM}}$; Centaur Services, UK), $30 \mathrm{~min}$ and immediately before, and 30, 60, 90, 120 and 180 min after dosing the glucose load. Whole blood was mixed with hemolysis reagent and blood glucose was measured in duplicate using the Sigma Enzymatic (Glucose Oxidase Trinder; ThermoFisher Microgenics, UK) colorimetric method and a SpectraMax 250 (Molecular Devices Corporation, Sunnyvale, CA, USA).

Insulin. Plasma insulin levels were measured using a murine insulin ELISA kit (CrystalChem, USA) according to the manufacturer's recommendation. Whole blood was collected into EDTA tubes and spun at 3,000 $\mathrm{g}$ for $5 \mathrm{~min}$ at $4{ }^{\circ} \mathrm{C}$ and the plasma stored at $-80{ }^{\circ} \mathrm{C}$ prior to analysis. Plasma samples were assayed in duplicate and the absorbance of both unknowns and standards measured using the Spectromax at $450 \mathrm{~nm}$.

\section{ASSOCIATED CONTENT}


Supporting Information. Experimental procedures for synthesis and determination of solubility, activity of $\alpha$-linolenic acid, $\mathbf{1}$ and $\mathbf{7}$ on FFA4 receptor mutants, activity of $\mathbf{1 0}$ on hFFA4, relative blood glucose changes in oral glucose tolerance test. This material is available free of charge via the Internet at http://pubs.acs.org.

AUTHOR INFORMATION

Corresponding Author

*Phone: +45 6550 2568. E-mail: $\underline{\text { ulven@s,sdu.dk. }}$

\section{Present Addresses}

$\dagger$ If an author's address is different than the one given in the affiliation line, this information may be included here.

\section{Author Contributions}

The manuscript was written through contributions of all authors. All authors have given approval to the final version of the manuscript.

\section{Funding Sources}

The Danish Council for Strategic Research (grant 11-116196) and the University of Southern Denmark for financial support.

\section{Notes}

BDH, GM and TU are shareholders of Caldan Therapeutics.

ACKNOWLEDGMENT 
We thank Britt Grathwohl, Eugenia Sergeev and Maria Due-Hansen for helpful input and assistance.

\begin{abstract}
ABBREVIATIONS
BRET, bioluminescence resonance energy transfer; DMEDA, $N, N$ '-dimethylethylenediamine; FaSSIF, fasted state simulated intestinal fluid; FFA1, free fatty acid receptor 1 (GPR40); FFA2, free fatty acid receptor 2 (GPR43); FFA3, free fatty acid receptor 3 (GPR41); FFA4, free fatty acid receptor 4 (GPR120); HBSS, Hanks' balanced salt solution; nr, no response; PE, petroleum ether.
\end{abstract}

\title{
REFERENCES
}

(1) Offermanns, S. Free fatty acid (FFA) and hydroxy carboxylic acid (HCA) receptors. Annu. Rev. Pharmacol. Toxicol. 2014, 54, 407-434.

(2) Moniri, N. H. Free-fatty acid receptor-4 (GPR120): cellular and molecular function and its role in metabolic disorders. Biochem. Pharmacol. 2016, 110-111, 1-15.

(3) Cornall, L. M.; Mathai, M. L.; Hryciw, D. H.; McAinch, A. J. GPR120 agonism as a countermeasure against metabolic diseases. Drug Discov. Today 2014, 19, 670-679.

(4) Hara, T.; Kimura, I.; Inoue, D.; Ichimura, A.; Hirasawa, A. Free fatty acid receptors and their role in regulation of energy metabolism. Rev. Physiol., Biochem. Pharmacol. 2013, 164, 77116.

(5) Ulven, T.; Christiansen, E. Dietary Influences on Regulation of the Long-Chain Fatty Acid Receptor FFA4/GPR120. Annu. Rev. Nutr. 2015, 35, 239-263. 
(6) Milligan, G.; Alvarez-Curto, E.; Watterson, K. R.; Ulven, T.; Hudson, B. D. Characterising pharmacological ligands to study the long chain fatty acid receptors GPR40/FFA1 and GPR120/FFA4. Br. J. Pharmacol. 2015, 172, 3254-3265.

(7) Milligan, G.; Shimpukade, B.; Ulven, T.; Hudson, B. D. Complex Pharmacology of Free Fatty Acid Receptors. Chem. Rev. 2016, doi:10.1021/acs.chemrev.1026b00056.

(8) Hirasawa, A.; Tsumaya, K.; Awaji, T.; Katsuma, S.; Adachi, T.; Yamada, M.; Sugimoto, Y.; Miyazaki, S.; Tsujimoto, G. Free fatty acids regulate gut incretin glucagon-like peptide-1 secretion through GPR120. Nature Med. 2005, 11, 90-94.

(9) Paulsen, S. J.; Larsen, L. K.; Hansen, G.; Chelur, S.; Larsen, P. J.; Vrang, N. Expression of the fatty acid receptor GPR120 in the gut of diet-induced-obese rats and its role in GLP-1 secretion. PLoS One 2014, 9, e88227.

(10) Oh, D. Y.; Talukdar, S.; Bae, E. J.; Imamura, T.; Morinaga, H.; Fan, W. Q.; Li, P. P.; Lu, W. J.; Watkins, S. M.; Olefsky, J. M. GPR120 is an omega-3 fatty acid receptor mediating potent anti-inflammatory and insulin-sensitizing effects. Cell 2010, 142, 687-698.

(11) Ichimura, A.; Hirasawa, A.; Poulain-Godefroy, O.; Bonnefond, A.; Hara, T.; Yengo, L.; Kimura, I.; Leloire, A.; Liu, N.; Iida, K.; Choquet, H.; Besnard, P.; Lecoeur, C.; Vivequin, S.; Ayukawa, K.; Takeuchi, M.; Ozawa, K.; Tauber, M.; Maffeis, C.; Morandi, A.; Buzzetti, R.; Elliott, P.; Pouta, A.; Jarvelin, M.-R.; Korner, A.; Kiess, W.; Pigeyre, M.; Caiazzo, R.; Van Hul, W.; Van Gaal, L.; Horber, F.; Balkau, B.; Levy-Marchal, C.; Rouskas, K.; Kouvatsi, A.; Hebebrand, J.; Hinney, A.; Scherag, A.; Pattou, F.; Meyre, D.; Koshimizu, T.-a.; Wolowczuk, I.; Tsujimoto, G.; Froguel, P. Dysfunction of lipid sensor GPR120 leads to obesity in both mouse and human. Nature 2012, 483, 350-354. 
(12) Oh da, Y.; Walenta, E.; Akiyama, T. E.; Lagakos, W. S.; Lackey, D.; Pessentheiner, A. R.; Sasik, R.; Hah, N.; Chi, T. J.; Cox, J. M.; Powels, M. A.; Di Salvo, J.; Sinz, C.; Watkins, S. M.; Armando, A. M.; Chung, H.; Evans, R. M.; Quehenberger, O.; McNelis, J.; Bogner-Strauss, J. G.; Olefsky, J. M. A Gpr120-selective agonist improves insulin resistance and chronic inflammation in obese mice. Nature Med. 2014, 20, 942-947.

(13) Engelstoft, M. S.; Park, W. M.; Sakata, I.; Kristensen, L. V.; Husted, A. S.; OsborneLawrence, S.; Piper, P. K.; Walker, A. K.; Pedersen, M. H.; Nohr, M. K.; Pan, J.; Sinz, C. J.; Carrington, P. E.; Akiyama, T. E.; Jones, R. M.; Tang, C.; Ahmed, K.; Offermanns, S.; Egerod, K. L.; Zigman, J. M.; Schwartz, T. W. Seven transmembrane G protein-coupled receptor repertoire of gastric ghrelin cells. Mol. Metab. 2013, 2, 376-392.

(14) Suckow, A. T.; Polidori, D.; Yan, W.; Chon, S.; Ma, J. Y.; Leonard, J.; Briscoe, C. P. Alteration of the glucagon axis in GPR120 (FFAR4) knockout mice: a role for GPR120 in glucagon secretion. J. Biol. Chem. 2014, 289, 15751-15763.

(15) Stone, V. M.; Dhayal, S.; Brocklehurst, K. J.; Lenaghan, C.; Sorhede Winzell, M.; Hammar, M.; Xu, X.; Smith, D. M.; Morgan, N. G. GPR120 (FFAR4) is preferentially expressed in pancreatic delta cells and regulates somatostatin secretion from murine islets of Langerhans. Diabetologia 2014, 57, 1182-1191.

(16) Egerod, K. L.; Engelstoft, M. S.; Lund, M. L.; Grunddal, K. V.; Zhao, M.; Barir-Jensen, D.; Nygaard, E. B.; Petersen, N.; Holst, J. J.; Schwartz, T. W. Transcriptional and Functional Characterization of the G Protein-Coupled Receptor Repertoire of Gastric Somatostatin Cells. Endocrinology 2015, 156, 3909-3923. 
(17) Christiansen, E.; Watterson, K. R.; Stocker, C. J.; Sokol, E.; Jenkins, L.; Simon, K.; Grundmann, M.; Petersen, R. K.; Wargent, E. T.; Hudson, B. D.; Kostenis, E.; Ejsing, C. S.; Cawthorne, M. A.; Milligan, G.; Ulven, T. Activity of dietary fatty acids on FFA1 and FFA4 and characterization of pinolenic acid as a dual FFA1/FFA4 agonist with potential effect against metabolic diseases. Br. J. Nutr. 2015, 113, 1677-1688.

(18) Shimpukade, B.; Hudson, B. D.; Hovgaard, C. K.; Milligan, G.; Ulven, T. Discovery of a Potent and Selective GPR120 Agonist. J. Med. Chem. 2012, 55, 4511-4515.

(19) Christiansen, E.; Due-Hansen, M. E.; Urban, C.; Merten, N.; Pfleiderer, M.; Karlsen, K. K.; Rasmussen, S. S.; Steensgaard, M.; Hamacher, A.; Schmidt, J.; Drewke, C.; Petersen, R. K.; Kristiansen, K.; Ullrich, S.; Kostenis, E.; Kassack, M. U.; Ulven, T. Structure-activity study of dihydrocinnamic acids and discovery of the potent FFA1 (GPR40) agonist TUG-469. ACS Med. Chem. Lett. 2010, 1, 345-349.

(20) Hudson, B. D.; Shimpukade, B.; Mackenzie, A. E.; Butcher, A. J.; Pediani, J. D.; Christiansen, E.; Heathcote, H.; Tobin, A. B.; Ulven, T.; Milligan, G. The Pharmacology of TUG-891, a Potent and Selective Agonist of the Free Fatty Acid Receptor 4 (FFA4/GPR120), Demonstrates Both Potential Opportunity and Possible Challenges to Therapeutic Agonism. Mol. Pharmacol. 2013, 84, 710-725.

(21) Arakawa, K.; Nishimura, T.; Sugimoto, Y.; Takahashi, H.; Shimamura, T. Preparation of heteroaryloxyphenyldihydrobenzisothiazoledioxide derivatives and analogs for use as GPR120 receptor modulators. WO2010104195A1.

(22) Sparks, S. M.; Chen, G.; Collins, J. L.; Danger, D.; Dock, S. T.; Jayawickreme, C.; Jenkinson, S.; Laudeman, C.; Leesnitzer, M. A.; Liang, X.; Maloney, P.; McCoy, D. C.; Moncol, 
D.; Rash, V.; Rimele, T.; Vulimiri, P.; Way, J. M.; Ross, S. Identification of diarylsulfonamides as agonists of the free fatty acid receptor 4 (FFA4/GPR120). Bioorg. Med. Chem. Lett. 2014, 24, 3100-3103.

(23) Christiansen, E.; Urban, C.; Merten, N.; Liebscher, K.; Karlsen, K. K.; Hamacher, A.; Spinrath, A.; Bond, A. D.; Drewke, C.; Ullrich, S.; Kassack, M. U.; Kostenis, E.; Ulven, T. Discovery of potent and selective agonists for the free fatty acid receptor 1 (FFA1/GPR40), a potential target for the treatment of type II diabetes. J. Med. Chem. 2008, 51, 7061-7064.

(24) Hudson, B. D.; Shimpukade, B.; Milligan, G.; Ulven, T. The molecular basis of ligand interaction at free fatty acid receptor 4 (FFA4/GPR120). J. Biol. Chem. 2014, 289, 20345-20358.

(25) Shelley, J. C.; Cholleti, A.; Frye, L. L.; Greenwood, J. R.; Timlin, M. R.; Uchimaya, M. Epik: a software program for $\mathrm{pK}(\mathrm{a})$ prediction and protonation state generation for drug-like molecules. J. Comput. Aided Mol. Des. 2007, 21, 681-691.

(26) Christiansen, E.; Hansen, S. V. F.; Urban, C.; Hudson, B. D.; Wargent, E. T.; Grundmann, M.; Jenkins, L.; Zaibi, M.; Stocker, C. J.; Ullrich, S.; Kostenis, E.; Kassack, M. U.; Milligan, G.; Cawthorne, M. A.; Ulven, T. Discovery of TUG-770: A Highly Potent Free Fatty Acid Receptor 1 (FFA1/GPR40) Agonist for Treatment of Type 2 Diabetes. ACS Med. Chem. Lett. 2013, 4, 441-445.

(27) Sun, P.; Wang, T.; Zhou, Y.; Liu, H.; Jiang, H.; Zhu, W.; Wang, H. DC260126: a smallmolecule antagonist of GPR40 that protects against pancreatic beta-Cells dysfunction in $\mathrm{db} / \mathrm{db}$ mice. PLoS One 2013, 8, e66744. 
(28) Zhang, X. D.; Yan, G. R.; Li, Y. M.; Zhu, W. L.; Wang, H. Y. DC260126, a smallmolecule antagonist of GPR40, improves insulin tolerance but not glucose tolerance in obese Zucker rats. Biomedicine \& Pharmacotherapy 2010, 64, 647-651.

(29) Taneera, J.; Lang, S.; Sharma, A.; Fadista, J.; Zhou, Y.; Ahlqvist, E.; Jonsson, A.; Lyssenko, V.; Vikman, P.; Hansson, O.; Parikh, H.; Korsgren, O.; Soni, A.; Krus, U.; Zhang, E.; Jing, X. J.; Esguerra, J. L.; Wollheim, C. B.; Salehi, A.; Rosengren, A.; Renstrom, E.; Groop, L. A systems genetics approach identifies genes and pathways for type 2 diabetes in human islets. Cell Metab. 2012, 16, 122-134.

(30) Vestmar, M. A.; Andersson, E. A.; Christensen, C. R.; Hauge, M.; Glumer, C.; Linneberg, A.; Witte, D. R.; Jorgensen, M. E.; Christensen, C.; Brandslund, I.; Lauritzen, T.; Pedersen, O.; Holst, B.; Grarup, N.; Schwartz, T. W.; Hansen, T. Functional and genetic epidemiological characterisation of the FFAR4 (GPR120) p.R270H variant in the Danish population. J. Med. Genet. 2016, doi:10.1136/jmedgenet-2015-103728.

(31) Rasmussen, S. G. F.; Choi, H.-J.; Fung, J. J.; Pardon, E.; Casarosa, P.; Chae, P. S.; DeVree, B. T.; Rosenbaum, D. M.; Thian, F. S.; Kobilka, T. S.; Schnapp, A.; Konetzki, I.; Sunahara, R. K.; Gellman, S. H.; Pautsch, A.; Steyaert, J.; Weis, W. I.; Kobilka, B. K. Structure of a nanobody-stabilized active state of the $\beta_{2}$ adrenoceptor. Nature 2011, 469, 175-180.

(32) Sali, A.; Blundell, T. L. Comparative Protein Modeling by Satisfaction of Spatial Restraints. J. Mol. Biol. 1993, 234, 779-815.

(33) Kundu, N. G.; Khan, M. W.; Mukhopadhyay, R. Heteroannulation through combined palladium catalysed and friedel-crafts reactions strategy: Synthesis of 3-alkylidene isoiodolin-1ones. Tetrahedron 1999, 55, 12361-12376. 
(34) Olsson, M. H.; Sondergaard, C. R.; Rostkowski, M.; Jensen, J. H. PROPKA3: Consistent Treatment of Internal and Surface Residues in Empirical pKa Predictions. J Chem Theory Comput 2011, 7, 525-537.

(35) Schrödinger Release 2015-3: MacroModel, version 10.9, Schrödinger, LLC, New York, NY, 2015.

(36) Schrödinger Release 2015-3: LigPrep, version 3.5, Schrödinger, LLC, New York, NY, 2015.

(37) Kang, S. K.; Ryu, H. C.; Lee, S. W. Ni(acac)(2)-catalyzed cross-coupling and carbonylative cross-coupling of organostannanes with hypervalent iodonium salts. J. Chem. Soc., Perkin Trans. 1 1999, 2661-2663.

(38) Cho, C. S.; Oh, B. H.; Shim, S. C. Synthesis of quinolines by ruthenium-catalyzed heteroannulation of anilines with 3-amino-1-propanol. J. Heterocycl. Chem. 1999, 36, 11751178.

(39) Wargent, E. T.; Zaibi, M. S.; O'Dowd, J. F.; Cawthorne, M. A.; Wang, S. J.; Arch, J. R.; Stocker, C. J. Evidence from studies in rodents and in isolated adipocytes that agonists of the chemerin receptor CMKLR1 may be beneficial in the treatment of type 2 diabetes. PeerJ 2015, $3, \mathrm{e} 753$. 
Insert Table of Contents Graphic and Synopsis Here

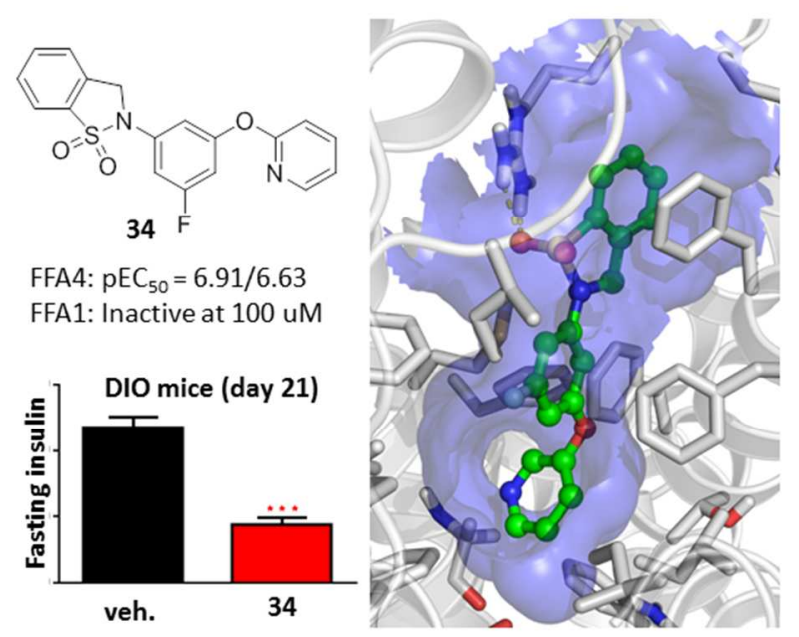

